Nova Southeastern University

Florida

NSUWorks

Summer 1-1-2013

\title{
Tidying up the Internet: Take Down of Unauthorized Content under Copyright, Trademark and Defamation Law
}

Jon M. Garon

Follow this and additional works at: https://nsuworks.nova.edu/law_facarticles

\section{Recommended Citation}

Jon M. Garon, Tidying Up the Internet: Take Down of Unauthorized Content under Copyright, Trademark and Defamation Law, 41 CAPITAL U. L. REV. 513 (2013).

This Article is brought to you for free and open access by the Shepard Broad College of Law at NSUWorks. It has been accepted for inclusion in Faculty Scholarship by an authorized administrator of NSUWorks. For more information, please contact nsuworks@nova.edu. 


\title{
Capital University Law Review
}

\author{
COPYRIGHT C 2013 BY THE CAPITAL UNIVERSITY LAW REVIEW
}

\begin{tabular}{lll}
\hline Volume 41 & Summer 2013 & Number 3 \\
\hline
\end{tabular}

\section{ARTICLES}

Adjustments, Extensions, Disclaimers, and Continuations: When Do Patent Term Adjustments Make Sense?

Stephanie Plamondon Bair

Tidying up the Internet: Takedown of Unauthorized Content under

Copyright, Trademark, and Defamation Law....

Jon M. Garon

The Ralston-Landreth-Gustafson Harmony: A Security!

Nicholas L. Georgakopoulos

A Polemic Against the Standing Requirement in Constitutional Cases

Jeremy Patrick

Gödel's Loophole

F.E. Guerra-Pujol

Free to be Fracked: The Curious Constitutional Consequences of Ohio Gas

Law

James T. O'Reilly

\section{COMMENTS}

The Reexamination Power of Patent Infringers and the Forgotten Inventor Douglas Duff

The Public is Paying Twice: How Stanford v. Roche Undermines the Congressional Intent of the Bayh-Dole Act.

Ashlie Depinet 


\title{
CAPITAL UNIVERSITY LAW REVIEW
}

\section{2-2013 EDITORIAL BOARD}

\author{
Editor-in-Chief \\ ALEXIS M. HADDOX
}

Managing Editor

COREY T. LEGGETT

\author{
Executive Publishing Editor \\ Executive Articles Editor \\ CHRISTOPHER M. POTTERTON \\ KEONA R. PADGETT
}

Articles Editors

RALPH BUTCHER

CAROLINE J. DYER

JASON T. GERKEN

TROY M. HARTER

ANNA S. LOU

KACIE D. WAUGH

\author{
Associate Content Editors \\ Douglas J. DUFF \\ Caroline Helmick MCNally \\ ABBIE E. OBENOUR
}

Associate Note Editors

\author{
PAUL AKER \\ JESSE L. BRANNER \\ RENA N. PASSAS \\ MICHAEL J. SHARVIN
}

\section{Staff Members}

JOSEPH ARNOLD

E. JOSEPH D'ANDREA

ANDREW FULLENKAMP

NICK HORN

SEAN M. KILBANE

MIRANDA M. MCKELVEY

KARI R. ROUSH

JUSTIN SCHIFF

TRENT THACKER
LUCAS P. BAKER

LINDSAY F. DUNN

STEPHANIE FULLER

JENNIFER L. HUBER

SARAH J. KROPP

MITZI MOODY

LAKSHMI SATYANARAYANA

REED D. SEARCY

\author{
JOSHUA C. BERNS \\ LORIBETH KOWALSKI \\ NICK PETTEY \\ ALYSON N. VARDA
}

ERIC E. Coss

Nicholas M. FranchaK

PATRICK J. HEERY

JACKIE JEWELL

RACHEL E. LUSK

ERIN PORTA

RICHARD M. SCHANZ

JOEL SPROUT

JENNA WALDO

\section{Advisors}

Professor James R. BeAtTIE

PROFESSOR DANIEL T. KoBIL 


\title{
CAPITAL UNIVERSITY LAW SCHOOL
}

\author{
ADMINISTRATIVE OFFICERS \\ Richard C. Simpson, B.A., J.D., Dean and Professor of Law \\ Rachel M. Janutis, B.S., J.D., Associate Dean of Academic Affairs and Professor of Law
}

\section{FACULTY EMERITI}

Carole C. Berry, B.S., J.D., Ph.D., Professor Emeritus

Roberta S. Mitchell, B.A., J.D., Professor Emeritus

Hayward D. Reynolds, A.B., J.D., Professor Emeritus

Robert Wade, B.S., J.D., LL.M., Professor Emeritus

\section{FACULTY}

Scott Anderson, B.A., J.D., Ph.D., Professor of Legal Research and Writing James R. Beattie, Jr., B.A., M.A., J.D., LL.M., Professor of Law

Janet George Blocher, B.A., J.D., Professor of Legal Research and Writing

William H. Bluth, B.A., J.D., Professor of Law

Kimberly Breedon, B.A., M.A., J.D., LL.M., Visiting Assistant Professor of Law

Mark R. Brown, B.S., J.D., LL.M., Newton D. Baker/Baker and Hostetler Chair of Law

Thomas C. Brown, B.S., J.D., M.L.I.S., Professor of Legal Research and Writing

Regina F. Burch, A.B., M.S.A., J.D., Professor of Law, Associate Dean for Graduate Programs

Charles E. Cohen, B.A., J.D., Associate Professor of Law

Margaret M. Cordray, B.A., J.D., B.C.L., Professor of Law, Co-Director of Academic Success Program

Stanton G. Darling, II, B.A., J.D., Professor of Law

Michael Distelhorst, B.A., J.D., Professor of Law

Jeffrey T. Ferriell, B.S., J.D., LL.M., Professor of Law

César Cuauhtémoc García Hernández, A.B., J.D., Assistant Professor of Law

Susan M. Gilles, LL.B., LL.M., Professor Emeritus John E. Sullivan Designated Professor of Law, Director of Faculty Development

Joseph K. Grant, A.B., J.D., Associate Professor of Law

Myron C. Grauer, B.A., J.D., LL.M., Professor of Law

Jack A. Guttenberg, B.A., J.D., Professor of Law

Dennis D. Hirsch, B.A., J.D., Geraldine W. Howell Professor of Law

Donald A. Hughes, Jr., B.A., M.A., M.L.S., J.D., Professor of Lan, Director of Law Library

Daniel T. Kobil, B.A., J.D., Professor of Law, Co-Director of Academic Success Program

Risa Dinitz Lazaroff, A.B., J.D., Professor of Legal Research and Writing

Susan E. Looper-Friedman, B.A., J.D., LL.M., Professor of Law

David N. Mayer, A.B., J.D., M.A., Ph.D., Professor of Law

Melinda S. Molina, B.S., J.D., Assistant Professor of Law, Co-Director of Academic Success Program

Jacqueline M. Orlando, B.A., M.L.S., J.D., Professor of Legal Research and Writing, Associate Director of Library Public Services

Karen Rosenberg, B.S., M.A., J.D., Professor of Legal Research and Writing

Susan Simms, B.A., M.Ed., Ed.S., J.D., Professor of Legal Research and Writing, Director of Extern Program

Bradley A. Smith, B.A., J.D., Josiah H. Blackmore II/Shirley M. Nault Designated Professor of Law

Jeffrey C. Snapp, B.A., J.D., Professor of Legal Research and Writing

Fenner Stewart, B.A., J.D., LL.M., Ph.D. (Candidate), Assistant Professor of Law

Mark P. Strasser, B.A., M.A., Ph.D., J.D., Trustees Professor of Law

Lance Tibbles, B.S., J.D., Professor of Law, Director of Ethics Institute

Daniel C. Turack, B.A., LL.B., LL.M., S.J.D., Professor of Law

Yvonne Lundwall Twiss, B.A., J.D., Professor and Director of Bar Studies

Angela Upchurch, B.A., J.D., Professor of Law

Floyd D. Weatherspoon, B.S., J.D., Professor of Law, Associate Dean of Alternative Dispute Resolution Programs

Richard J. Wood, B.A., J.D., LL.M., Professor of Law 


\section{GENERAL LITIGATION CLINIC}

Danny W. Bank, A.A.S., B.A., J.D., Professor of Clinical Studies and Director of Legal Clinic Lorie L. McCaughan, R.N., B.S.N., J.D., Professor of Clinical Studies and Co-Director of Legal Clinic Eric McLoughlin, B.A., J.D., General Litigation Clinic, Small Business Section

\section{FAMILY ADVOCACY CLINIC ATTORNEYS}

Cara Dawson, B.S., J.D.

Elizabeth O'Leary, B.A., J.D.

Cheryl Midian, B.S., M.B.A., J.D.

Jessica Samuel, B.A., J.D.

Sara Smith, B.A., J.D.

Joshua Werning, B.A., J.D.

Melissa Wick, B.A., J.D.

\section{LIBRARY}

Donald A. Hughes, Jr., B.A., M.A., M.L.S., J.D., Professor of Law and Director of Law Library Wendy M. Medvetz, B.S., M.L.S., Acquisitions Librarian Jacqueline M. Orlando, B.A., M.L.S., J.D., Associate Director for Public Services Phyllis C. Post, B.A., M.S., Head of Technical Services

\section{NATIONAL CENTER FOR ADOPTION LAW \& POLICY}

Denise St. Clair, B.A., J.D., Executive Director

Fawn Gadel, B.S.B.A., J.D., Staff Attorney

Rosemary Pomeroy, B.A., J.D., Staff Attorney

Marsha Wickliffe, B.A., J.D., Staff Attorney 


\section{ADJUNCT FACULTY}

Alan S. Acker, B.S., J.D., I.I.T.

Thomas Addessa, B.S., J.D.

Jane S. Arata, B.A., J.D.

Phillip B. Bartlett, B.S.B.A., J.D.

John Beavers, B.A., J.D.

Edward J. Bernert, B.A., J.D.

David S. Bloomfield, B.S., J.D.

Timothy Boone, B.S., J.D.

Brenda Bowers, B.A., J.D.

Robert Brubaker, B.A., J.D.

Jeffrey Chilcoat, B.A., J.D.

Edward R. Claggett, B.S., J.D., LL.M.

Jeanne Clement, Ph.D.

Stephanie Demers, B.A., M.B.A., J.D.

Scot E. Dewhirst, B.A., J.D.

Jason M. Dolin, B.A., J.D.

Michael Dortch, B.A., J.D.

Alan D. Duffy, B.A., J.D., LL.M.

Mark Engle, B.A., J.D., L.L.M.

Todd A. Ernsberger, B.A., J.D., LL.M.

Lisa Eschleman, B.S.P.A., J.D.

William Fischbein, B.A., J.D.

F. James Foley, B.A., J.D.

Kevin Foley, B.A., J.D.

Judge Gregory Frost, B.A., J.D.

Philip J. Fulton, B.A., J.D.

John M. Gonzales, B.A., J.D.

Terrence A. Grady, B.A., J.D., LL.M.

Stephen Grant, B.S., J.D.

Kevin R. Griffith, B.A., M.A., Ph.D.

David W. Hardymon, B.A., J.D.

Jeremy Heck, B.S., J.D.

Katherine R. Herron, B.A., J.D., LL.M.

Cynthia J. Hoffman, B.S.B.A, J.D.

Christopher Hogan, B.A., J.D.

Richard W. Holz, B.S., J.D.

Janine Jones, B.A., J.D.

Shawn Judge, B.A., M.A., J.D.

\section{GRADUATE LAW FACULTY}

Alan S. Acker, B.S., J.D.

Philip B. Bartlett, B.S.B.A., J.D.

Edward J. Bernert, B.A., J.D.

David S. Bloomfield, B.S., J.D.

Edward R. Claggett, B.S., J.D., LL.M.

Todd A. Emsberger, B.A., J.D., LL.M.

Terrence A. Grady, B.A., J.D., LL.M.
Deborah A. Katz, B.A., J.D., M.A., Ph.D.

Hon. Terence P. Kemp, B.A., J.D.

Francis A. Kovacs-Colon, Jr., B.A., J.D., LL.M.

Richard Lavoie, A.B., J.D., LL.M.

Michael S. Lehv, A.B., M.D., J.D.

Shannon Leis, B.A., J.D.

Mark Lewis, B.A., J.D., LL.M.

Teresa Liston, B.A., J.D.

James L. Lowe, B.A., J.D.

James P. Luton, B.A., J.D.

Amy Mass, B.A., J.D.

Larry A. McElwee, B.A., M.A., J.D., Ph.D.

Michael Mess, B.A., J.D., LL.M.

Susan Nagel, B.A., J.D., LL.M.

Vincent J. Nardone, B.S., J.D., LL.M.

Adam Nemann, B.A., J.D.

Robert J. Onda, B.S., J.D., LL.M.

Howard Petricoff, B.S., J.D., M.P.A.

Tanya J. Poteet, B.A., J.D., M.A., Ph.D.

Amanda Powell, B.S., J.D.

Larry Ray, B.A., J.D.

Nicholas M.J. Ray, B.S.S.A., J.D., LL.M.

Allen L. Rutz, B.S., M.S., J.D.

Nancy P. Sabol, B.A., J.D.

Jeffrey Sammons, B.B.A., J.D.

Matthew Schrader, B.A., J.D.

Christopher Schraff, A.B., J.D.

E. Dale Searcy, B.S.M.E., J.D., LL.M.

Elizabeth Luper Schuster, B.A., J.D.

David I. Shroyer, B.A., J.D.

Evelyn Smith, B.S., J.D.

Stephen J. Smith, B.A., J.D.

Douglas W. Squires, B.A., J.D.

John M. Stephen, B.A., J.D.

Richard E. Trogolo, B.S., J.D.

Stephen C. Veltri, B.A., J.D., LL.M.

Robert J. Weiler, B.S., M.A., J.D., Ph.D.

Terrence Wheeler, B.A., J.D.

Francis A. Kovacs-Colon, Jr., B.A., J.D., LL.M Vincent J. Nardone, B.S., B.A., J.D., LL.M.

Robert J. Onda, B.S., J.D., LL.M.

Nicholas M.J. Ray, B.S.S.A., J.D., LL.M.

Jeffrey Sammons, B.B.A., J.D.

Richard E. Trogolo, B.S., J.D.

Steve Zisser, B.A., J.D., LL.M. 


\section{TIDYING UP THE INTERNET: TAKEDOWN OF UNAUTHORIZED CONTENT UNDER COPYRIGHT, TRADEMARK, AND DEFAMATION LAW JON M. GARON*}

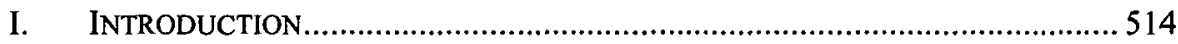

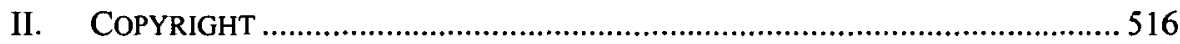

A. Red Flag Test Adds Little ..................................................... 520

B. Counter Notification.............................................................. 523

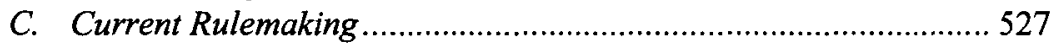

III. DEFAMATION AND HARMFUL SPEECH...................................................... 528

A. Online Defamation Generally ............................................. 528

$B$. Third-Party Limitations from the Communications Decency

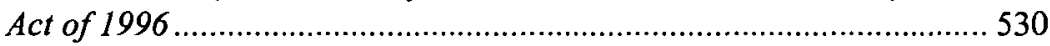

C. Responses to Harmful Speech................................................. 533

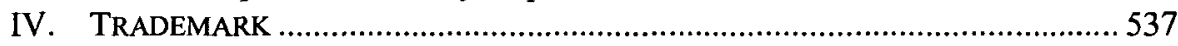

A. Trademarks and Internet Speech ............................................538

B. Early Commercial Battles-Links, Frames, Domains, and

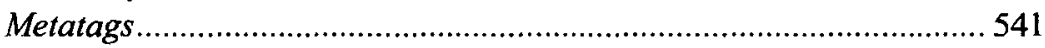

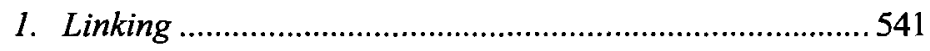

2. Framing................................................................. 543

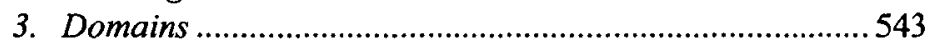

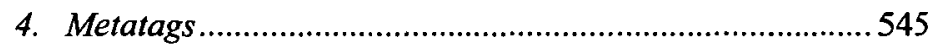

C. New Battles-Keyword Advertising ........................................... 546

D. Final Words-Eternal Diligence ................................................. 551

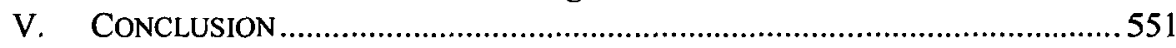

Copyright $\odot 2013$, Jon M. Garon.

- Director, NKU Chase Law + Informatics Institute and Professor of Law, Northern Kentucky University Salmon P. Chase College of Law; J.D. Columbia University School of Law 1988. Prepared for use with the ABA Business Law Section, Cyberspace Committee program March 24, 2012. Special thanks to Susan Stephan, Of Counsel to Kretsch \& Gust, PLLC, for her assistance with the paper and organization of the program. 


\section{INTRODUCTION}

Websites, Internet retailers, and search engines (known as "information location tools") increasingly rely on their users to generate content, interest, transactions, and value. In the Wild West, which first characterized the development of the Internet, notions that Usenet sites and bulletin boards could —or should - be responsible for content posted by users of the services seemed antithetical to the online ethos. ${ }^{2}$

In response to early litigation regarding this third-party liability, ${ }^{3}$ Congress enacted legislation modifying copyright law $^{4}$ and defamation law ${ }^{5}$ to provide Web hosts broad immunity for indirect infringement.

By comparison, the statutory protection enacted for trademarks is limited to the unauthorized use of trademarks in domain names. ${ }^{6}$ Statutory protection has not yet developed for trademarks with respect to consumer postings or advertising purchased by third parties. Therefore, laws addressing unauthorized use of trademarks have evolved through the courts. ${ }^{7}$

Since the enactment of these various laws (defamation immunity in $1996{ }^{8}$ the copyright notice-and-takedown in $1998^{9}$ and anticybersquatting

\footnotetext{
${ }^{1} 17$ U.S.C. $\$ 512$ (d) (2006).

2 See, e.g., Tomasz R. Surmacz, Measurement of Data Flow in Usenet News Management, 5 MEASUREMENT SCI. REV. 47, 47 (2005) (discussing that articles or links posted to a Usenet Server are automatically distributed to the whole network of servers, which in turn makes monitoring the links difficult).

${ }^{3}$ See, e.g., Religious Tech. Ctr. v. Netcom On-Line Commc'n Servs., Inc., 907 F. Supp. 1361, 1368 (N.D. Cal. 1995).

${ }^{4} 17$ U.S.C. $\$ 512(a)$.

${ }^{5} 47$ U.S.C. $\$ 230(c)(1)$ ("No provider or user of an interactive computer service shall be treated as the publisher or speaker of any information provided by another information content provider.").

${ }^{6} 15$ U.S.C. $\$ 1125$ (d) (2006).

${ }^{7}$ See, e.g., Playboy Enter., Inc. v. Welles, 279 F.3d 796, 803-04 (9th Cir. 2002).

${ }^{8} 47$ U.S.C. $\S 230$. See also Ken S. Myers, Wikimmunity: Fitting the Communications Decency Act to Wikipedia, 20 HARV. J.L. \& TECH. 163, 165 (2006).

${ }^{9} 17$ U.S.C. § 512. See also The Digital Millennium Copyright Act of 1998, U.S. COPYRIGHT OFFICE 12 (Dec. 1998), http://www.copyright.gov/legislation/dmca.pdf.
} 
in $1999^{10}$ ), the Internet has moved from an interesting social phenomenon to a central component of social interaction and media engagement.

Facebook now boasts 845 million monthly active users, 250 million photos uploaded daily, and 2.7 billion "likes" and comments each day. ${ }^{11}$ YouTube boasts 48 hours of video uploaded per minute and 3 billion views each day. ${ }^{12}$ Content on these various social media sites has triggered complaints from companies worldwide. In 2011, Chilling Effects, a project of the Electronic Frontier Foundation, recorded 47,628 complaints from companies in the United States and slightly fewer from companies located outside the country. ${ }^{13}$

Twitter has received a number of complaints as well. In response, "Twitter has taken the unusual step of making [Digital Millennium Copyright Act] takedown notices public, in partnership with Chilling Effects ... and several universities. The site shows 4,410 cease and desist notices dating back to November 2010."14 While the percentage of complaints suggests that the notice-and-takedown system is only a minor aspect of the Internet media ecology, the existence of the system remains a source of tremendous anger for many. ${ }^{15}$

${ }^{10} 15$ U.S.C. $\& 1125(\mathrm{~d})$. See also W. Chad Shear, The Anticybersquatting Consumer Protection Act-An Offensive Weapon for Trademark Holders, 2001 U. ILL. J.L. TECH. \& POL'y 219, 219 (2001).

${ }^{11}$ Facebook, Inc., Registration Statement (Form S-1) (Feb. 1, 2012), available at http://www.sec.gov/Archives/edgar/data/1326801/000119312512034517/

d287954ds1.htm\#toc287954_2.

${ }^{12}$ Danny Goodwin, New YouTube Statistics: 48 Hours of Video Uploaded Per Minute; 3 Billion Views Per Day, SEARCh ENGINE WATCH (May 25, 2011), http://searchengine watch.com/article/2073962/New-YouTube-Statistics-48-Hours-of-Video-Uploaded-PerMinute-3-Billion-Views-Per-Day.

${ }^{13}$ Data from the Chilling Effects Clearinghouse, CHILLING EFFECTS, https://www. chillingeffects.org/stats (last visited Apr. 6, 2013).

${ }^{14}$ Jon Brodkin, Twitter Uncloaks a Year's Worth of DMCA Takedown Notices, 4,410 in All, ARS TECHNICA (Jan. 27, 2012, 2:50 PM), http://arstechnica.com/tech-policy/news/2012/ 01/twitter-uncloaks-a-years-worth-of-dmca-takedown-notices-4410-in-all.ars.

${ }^{15}$ See Tim Cushing, The True Damage of an Illegitimate DMCA Takedown Goes Much Further Than Simple "Inconvenience," TECHDIRT (Mar. 7, 2012), http://www.techdirt.com/ articles/20120306/15184918004/true-damage-illegitimate-dmca-takedown-goes-muchfurther-than-simple-inconvenience.shtml; Problems with Notice and Takedown, U. PENNSYLVANIA, http://tags.library.upenn.edu/project/35599 (last visited Feb. 22, 2013) (giving a collection of links to blogs and articles expressing anger regarding the DMCA). 
Moreover, significant litigation in the past year has refocused on using these legal tools to tidy the Internet and to cleanse it of unwanted or unauthorized content. ${ }^{16}$ This Article focuses on the recent activity in the courts and Congress regarding the various attempts to deal with unauthorized, unwanted, and controversial content available on the Internet.

\section{COPYRIGHT}

The notice-and-takedown provisions of the Digital Millennium Copyright Act (DMCA) were written in response to Religious Technology Center v. Netcom On-Line Communication Services, Inc. ${ }^{17}$ In this case, the Church of Scientology used copyright infringement actions to stop the unauthorized disclosure of church documents and teachings it treated as confidential. ${ }^{18}$ Although the court found no direct copyright infringement for the bulletin board service for hosting the content uploaded by the defendant, the court did not dismiss the claims of secondary liability based on the theory of contributory infringement. ${ }^{19}$ The court found that once the plaintiff had put the defendant on notice of the infringing content, the act of facilitating distribution of protected works could amount to substantial participation:

Providing a service that allows for the automatic distribution of all Usenet postings, infringing and noninfringing, goes well beyond renting a premises to an infringer.... Thus, it is fair, assuming Netcom is able to take simple measures to prevent further damage to plaintiffs' copyrighted works, to hold Netcom liable for contributory infringement where Netcom has knowledge of [the direct infringer's] infringing postings yet continues to aid in the accomplishment of [the infringer's] purpose of publicly distributing the postings. ${ }^{20}$

In light of the potentially broad common law secondary liability that could arise under Copyright, Congress enacted 17 U.S.C. $\S 512$. The goal

${ }^{16}$ See, e.g., UMG Recordings, Inc. v. Shelter Capital Partners LLC, 667 F.3d 1022 (9th Cir. 2011).

${ }^{17} 907$ F. Supp. 1361 (N.D. Cal. 1995).

${ }^{18} \mathrm{Id}$. at 1366 .

${ }^{19} \mathrm{Id}$. at 1382 .

${ }^{20} \mathrm{Id}$. at 1375 . 
was to provide immunity from ongoing liability in the event that an indirect infringer took expeditious action to remove allegedly infringing content. ${ }^{21}$

Section 512(c) applies to those systems that store and make data available at the request of the consumer:

Information Residing on Systems or Networks at Direction of Users.-

(1) In general.-A service provider shall not be liable for monetary relief, or, except as provided in subsection (j), for injunctive or other equitable relief, for infringement of copyright by reason of the storage at the direction of a user of material that resides on a system or network controlled or operated by or for the service provider, if the service provider-

(A)(i) does not have actual knowledge that the material or an activity using the material on the system or network is infringing;

(ii) in the absence of such actual knowledge, is not aware of facts or circumstances from which infringing activity is apparent; or

(iii) upon obtaining such knowledge or awareness, acts expeditiously to remove, or disable access to, the material;

(B) does not receive a financial benefit directly attributable to the infringing activity, in a case in which the service provider has the right and ability to control such activity; and

(C) upon notification of claimed infringement as described in paragraph (3), responds expeditiously to remove, or disable access to, the material that is claimed to be infringing or to be the subject of infringing activity. ${ }^{22}$

${ }^{21}$ See Perfect 10, Inc, v. CCBill, LLC, 340 F. Supp. 2d 1077, 1086 (C.D. Cal. 2004), aff'd in part, rev'd in part, 481 F.3d 751 (9th Cir. 2007).

${ }^{22} 17$ U.S.C. $\S 512(c)(2006)$. 
The first section of the statute closely mirrors the common law protection of secondary liability. ${ }^{23}$ Section $512(\mathrm{c})(1)(\mathrm{A})$ describes the copyright contributory liability standard. ${ }^{24}$ As the Supreme Court explained, "One infringes contributorily by intentionally inducing or encouraging direct infringement ... and infringes vicariously by profiting from direct infringement while declining to exercise a right to stop or limit it." 25

As to vicarious liability, in Viacom International v. YouTube, Inc., ${ }^{26}$ the Second Circuit held that the language of $\S 512(\mathrm{c})(1)(\mathrm{B})$ requires "something more" than the common law right and ability to control. ${ }^{27}$ The Viacom court rejected as legislative history as confusing and nondispositive. $^{28}$ The court explained that "if Congress had intended $\S 512(\mathrm{c})(1)(\mathrm{B})$ to be coextensive with vicarious liability, 'the statute could have accomplished that result in a more direct manner." 29 Instead, the "something more" requires that "a service provider exert[] substantial influence on the activities of users." ${ }^{, 30}$ If this substantial influence is demonstrated, then the service provider may be liable "without necessarily-or even frequently-acquiring knowledge of specific infringing activity." 31 The heightened influence is consistent with the Restatement approach to vicarious liability, which imputes all the actions of the agent to the principal when the agent is an employee ${ }^{32}$ or acting

${ }^{23}$ See, e.g., Metro-Goldwyn-Mayer Studios Inc. v. Grokster, Ltd., 545 U.S. 913, 930 (2005); Gershwin Publ'n Corp. v. Columbia Artists Mgmt., Inc., 443 F.2d 1159, 1162 (2d Cir. 1971).

${ }^{24} 17$ U.S.C. $\$ 512(\mathrm{c})(1)(\mathrm{A})$.

${ }^{25}$ Grokster, 545 U.S. at 930.

${ }^{26} 676$ F.3d 19 (2d Cir. 2012).

${ }^{27} \mathrm{Id}$. at 38.

${ }^{28}$ Id. at 37 ("Happily, the future of digital copyright law does not turn on the confused legislative history of the control provision.").

${ }^{29}$ Id. at 37 (emphasis added) (quoting UMG Recordings, Inc. v. Shelter Capital Partners LLC, 667 F.3d 1022, 1045 (9th Cir. 2011)).

${ }^{30} \mathrm{ld}$. at 38 .

${ }^{31}$ Id.

32 RESTATEMENT (THIRD) OF AGENCY \$ 7.03(2) (2006) ("A principal is subject to vicarious liability to a third party harmed by an agent's conduct when ... the agent is an employee who commits a tort while acting within the scope of employment...."). 
with, at least, apparent authority. ${ }^{33}$ The "something more" test of Viacom reconciles vicarious liability with its common-law roots.

The provisions of $\S 512(\mathrm{c})(1)$ allow courts to distinguish between those services that are materially participating in copyright violations with knowledge of their activities from those entities that can be used for infringement along with non-infringing activities. A service may avoid material participation provided that entity "responds expeditiously to remove, or disable access to" the material that is claimed to be infringing. ${ }^{34}$ The examples of this distinction may be more self-evident than the tests suggest. Litigated examples include YouTube ${ }^{35}$ and Veoh Networks, ${ }^{36}$ while Yahoo, Facebook, Rapidshare, and other services host usergenerated content and face similar scrutiny. While some of the users are undoubtedly uploading content that infringes exclusive rights of copyright owners, these services do not seek out these customers, provide preferential tools for infringement, or promote infringing activities in their materials. $^{37}$

In contrast to these services, those such as Napster, Grokster, and Streamcast materially contribute to the infringement activities of their user community. ${ }^{38}$ Most importantly, in separating these provisions, the courts tend to look at $\S 512(\mathrm{c})(1)(\mathrm{A})(\mathrm{ii})$, which imposes a duty when the content host becomes "aware of facts or circumstances from which infringing activity is apparent." 39

${ }^{33}$ Id. ("A principal is subject to vicarious liability to a third party harmed by an agent's conduct when ... the agent commits a tort when acting with apparent authority in dealing with a third party on or purportedly on behalf of the principal.").

${ }^{34} 17$ U.S.C. $\$ 512(\mathrm{c})(1)(\mathrm{C})(2006)$.

${ }^{35}$ Viacom, 718 F. Supp. $2 d$ at 527.

${ }^{36}$ UMG Recordings, Inc. v. Shelter Capital Partners LLC, 667 F.3d 1022, 1050 (9th Cir. 2011) (granting summary judgment for the hosting service).

${ }^{37}$ Cf. Metro-Goldwyn-Mayer Studios Inc. v. Grokster, Ltd., 545 U.S. 913, 935-36 (2005) (noting that using advertising to attract infringing customers, providing a good to aid in copyright infringement, and telling users how to participate in an infringing use are classic cases for finding copyright violations).

${ }^{38}$ See id. at 930-32 (providing cases where courts found that companies did or did not materially contribute to infringement activities).

${ }^{39} 17$ U.S.C. $\S 512(c)(1)(A)(i i)$. 


\section{A. Red Flag Test Adds Little}

This subsection has become known as the "red flag" test. Once the service provider becomes aware of these facts, it will lose the protection of the safe harbor unless it acts expeditiously. ${ }^{40}$ Despite the construction, however, the duty is on the copyright owner to make the service provider aware of these facts and circumstances. ${ }^{41}$ In Perfect 10, Inc. v. CCBill $L L C{ }^{42}$ for example, "there were a number of red flags that made it apparent infringing activity was afoot, noting that the defendant hosted sites with names such as 'illegal.net' and 'stolencelebritypics.com,' as well as password hacking websites, which obviously infringe." ${ }^{.43}$ These highly suggestive facts were not enough. Instead, the Ninth Circuit explained that it places no investigative duties on the service provider. ${ }^{44}$ As such, generalized knowledge of infringing use is insufficient to find secondary liability for a host. ${ }^{45}$

Once the copyright holder has provided the information, however, the service provider is under a duty to act expeditiously. ${ }^{46}$ Both the service provider and the copyright holder have certain duties to assure the system works. ${ }^{47}$ The service provider must provide a designated agent. ${ }^{48}$

${ }^{40}$ Id. $\S 512(\mathrm{c})(1)(\mathrm{A})(\mathrm{iii})$.

${ }^{41}$ Viacom Int'l Inc. v. YouTube, Inc., 676 F.3d 19, 32 (2d Cir. 2012) ("[W]e affirm the [d]istrict [c]ourt's holding that actual knowledge or awareness of facts or circumstances that indicate specific and identifiable instances of infringement will disqualify a service provider from the safe harbor.").

${ }^{42} 488$ F.3d 1102 (9th Cir. 2007).

${ }^{43}$ UMG Recordings, Inc. v. Shelter Capital Partners LLC, 667 F.3d 1022, 1038 (9th Cir. 2011) (quoting Perfect 10, 488 F.3d at 1114).

${ }^{44}$ Perfect 10,488 F.3d at 1114 .

${ }^{45}$ Id.

${ }^{46} \mathrm{Id}$. at 1111 .

${ }^{47} 17$ U.S.C. $\S 512(c)(2)-(3)(2006)$.

${ }^{48}$ Section 512(c)(2) states:

Designated agent.-The limitations on liability established in this subsection apply to a service provider only if the service provider has designated an agent to receive notifications of claimed infringement described in paragraph (3), by making available through its service, including on its website in a location accessible to the public, and by providing to the Copyright Office, substantially the following information: 
Assuming the agent has been designated properly, the copyright holder must provide notice to that agent in a form consistent with the statute to afford effective notice. ${ }^{49}$

(A) the name, address, phone number, and electronic mail address of the agent.

(B) other contact information which the Register of Copyrights may deem appropriate.

The Register of Copyrights shall maintain a current directory of agents available to the public for inspection, including through the Internet, in both electronic and hard copy formats, and may require payment of a fee by service providers to cover the costs of maintaining the directory.

Id. $\S 512(\mathrm{c})(2)$.

${ }^{49}$ Section 512(c)(3) states:

Elements of notification.-

(A) To be effective under this subsection, a notification of claimed infringement must be a written communication provided to the designated agent of a service provider that includes substantially the following:

(i) A physical or electronic signature of a person authorized to act on behalf of the owner of an exclusive right that is allegedly infringed.

(ii) Identification of the copyrighted work claimed to have been infringed, or, if multiple copyrighted works at a single online site are covered by a single notification, a representative list of such works at that site.

(iii) Identification of the material that is claimed to be infringing or to be the subject of infringing activity and that is to be removed or access to which is to be disabled, and information reasonably sufficient to permit the service provider to locate the material.

(iv) Information reasonably sufficient to permit the service provider to contact the complaining party, such as an address, telephone number, and, if available, an electronic mail address at which the complaining party may be contacted.

(v) A statement that the complaining party has a good faith belief that use of the material in the manner complained of is not authorized by the copyright owner, its agent, or the law.

(vi) A statement that the information in the notification is accurate, and under penalty of perjury, that the complaining party is authorized to

(continued) 
The notice is not difficult in form, but one providing a takedown notice must attend to the details with care. The work or works must be identified correctly, ${ }^{50}$ the notice must provide sufficient information to identify the location of the infringing work and source of the infringement ${ }^{51}$ and the copyright holder - or the authorized agent of the copyright holder-must attest that the complainant "has a good faith belief that use of the material in the manner complained of is not authorized by the copyright owner, its agent, or the law." ${ }^{2}$ Finally, the complainant must attest that the notice is accurate and authorized under penalty of perjury. ${ }^{53}$

There is no detailed, objective information on the attitude taken by various vendors regarding the process of takedown. Nonetheless, many use services such as Audible Magic or Vobile to create "digital fingerprints" of the files presented to the service provider. ${ }^{54}$ If those

act on behalf of the owner of an exclusive right that is allegedly infringed.

(B)(i) Subject to clause (ii), a notification from a copyright owner or from a person authorized to act on behalf of the copyright owner that fails to comply substantially with the provisions of subparagraph (A) shall not be considered under paragraph (I)(A) in determining whether a service provider has actual knowledge or is aware of facts or circumstances from which infringing activity is apparent.

(ii) In a case in which the notification that is provided to the service provider's designated agent fails to comply substantially with all the provisions of subparagraph (A) but substantially complies with clauses (ii), (iii), and (iv) of subparagraph (A), clause (i) of this subparagraph applies only if the service provider promptly attempts to contact the person making the notification or takes other reasonable steps to assist in the receipt of notification that substantially complies with all the provisions of subparagraph (A).

Id. $\S 512(\mathrm{c})(3)$.

${ }^{50} I d . \S 512(\mathrm{c})(3)(\mathrm{A})(\mathrm{ii})$.

${ }^{51} I d . \S 512(\mathrm{c})(3)(\mathrm{A})(\mathrm{iii})$.

${ }^{52} I d . \S 512(\mathrm{c})(3)(\mathrm{A})(\mathrm{v})$.

${ }^{53} I d . \S 512(\mathrm{c})(3)(\mathrm{A})(\mathrm{vi})$.

${ }^{54}$ Vobile Expands Copyright Infringement Technology, WALL ST. J. SPEAKEASY (Dec. 8, 2011, 5:31 PM), http://blogs.wsj.com/speakeasy/2011/12/08/vobile-expands-copyrightinfringement-technology/?KEYWORDS=Vobile. 
uploaded files match files in the database, the content is flagged and may be removed. ${ }^{55}$

Or maybe not. YouTube, for example, uses the software to match the digital fingerprint to the actual usage rights on file in its automated system. ${ }^{56}$ If the usage allows the file to be shown with advertising, then it adds a badge enabling the advertising. ${ }^{57}$ Using these types of tools, companies may be developing strategies to monetize and tacitly authorize what would otherwise have been unauthorized user-sourced third-party content. For example, a digital fingerprint of a cloud music sharing service could measure the number of times a song is uploaded as well as downloaded and streamed. This would make each event part of the license fee for the music and would re-associate any advertising with the usersourced content so that it legally takes on the same attributes as the authorized content on the site-as YouTube has done. ${ }^{58}$

\section{B. Counter Notification}

Although copyright holders must make a good faith determination that the material uploaded by third parties violates their exclusive rights, ${ }^{59}$ this may not mean that the copyright holders make bona fide assessments of fair use. Some owners may not be able to objectively consider that any use of their material is a fair use (notwithstanding the law on the matter), while others struggle to address hundreds or thousands of simultaneous infringements of a particular work and simply do not review the details of each unauthorized use.

${ }^{55}$ Id.

${ }^{56}$ Content ID, YouTuBE, http://www.youtube.com/t/contentid (last visited Feb. 22, 2013). YouTube answered the question, "How does Content ID work?" as follows:

Rights holders deliver YouTube reference files (audio-only or video) of content they own, metadata describing that content, and policies on what they want YouTube to do when we find a match.

We compare videos uploaded to YouTube against those reference files.

Our technology automatically identifies your content and applies your preferred policy: monetize, track, or block.

Id.

$$
\begin{aligned}
& { }^{57} I d . \\
& { }^{58} \text { See id. } \\
& { }^{59} 17 \text { U.S.C. } \$ 512(\mathrm{c})(3)(\mathrm{A})(\mathrm{v})(2006) .
\end{aligned}
$$


In addition to the disputes involving fair use, there may be mistakes in takedown notifications regarding the source of the work or the identity of the person who uploaded the content. Congress anticipated these issues by including a provision in the statute requiring subjects of takedown requests to respond to the notices. ${ }^{60}$

In other cases, the actions may be more intentional. In a filing by Verizon regarding a proposal to update the designation of agent, the telecommunications giant vented about the misuse of the takedown system:

While Verizon receives valid "notice and takedown" requests from copyright owners and responds promptly with the "take down" and counter-notification processes, we have unfortunately also experienced increasing misuses of the Designated Agent information located on the Copyright Office's website. The misuses fall into a variety of categories, including cases of (i) P2P and other file sharing activities where the material alleged to be infringed does not reside on a service provider's system or network, yet ISPs are often sent automated "takedown" notices by the thousands; (ii) allegations of trademark infringement, where the DMCA "notice and takedown" provision does not apply; (iii) material that is protected by the "fair use" defense of the Copyright Act; and (iv) abusive litigation tactics made in the alarming growth of "copyright troll" lawsuits. The latter involve legal motions often brought by those representing the "adult" entertainment industry who are using improper discovery tactics in federal and state courts to obtain the personal information (name, address and "Mac" number) of hundreds of ISP subscribers per case. In most instances, the litigation never proceeds as the intent is to extract multiple payments from thousands of defendants, many of whom are likely to settle due to the expense of defending the litigation and the embarrassing nature of the content alleged to be infringed. ${ }^{61}$

${ }^{60}$ Id. $\S 512(\mathrm{~g})$.

${ }^{61}$ Letter from Sarah B. Deutsch, Vice President and Assoc. Gen. Counsel, Verizon Commc'ns Inc., Re: Request for Public Comment on Designation of Agent to Receive (continued) 
The complaints regarding the abuse of the takedown system suggest that a number of other issues need to be addressed beyond merely the counter-notification process. Although an invalid notification creates no legal duty to respond, ${ }^{62}$ it will likely require the recipient to expend some time and effort to evaluate. As discussed subsequently, a notice-andtakedown system for trademarks, no matter how valid an infringement claim, simply does not exist. ${ }^{63}$ On the other hand, an Internet service provider (ISP) may not be a host to a peer-to-peer file-sharing site, but it might still provide "information location tools" in the form of links to the site or the ads promoting the illegal content. The information location tools are subject to $\S 512$ (d) takedown notifications and may be applicable to some of the situations described by Verizon. ${ }^{64}$

Noncompliant notifications, such as the identification of links or of trademark infringement could also build a record of actual knowledge of specific infringing activity. That record would support a claim for secondary liability in those areas where an ISP materially participates in the infringement. Google, for example, was involved in a case promoting pharmaceuticals that were illegally sold in the United States and was forced to disgorge a $\$ 500$ million payment, representing all of its own profits and the profits of the advertisers. ${ }^{65}$ ISPs and other large companies are not immune to liability for illegal conduct. Nonetheless, the frustration of Verizon reflects a real issue of overuse, at least in some instances.

For the average individual uploading to YouTube or another social media site, $\S 512(\mathrm{~g})$ provides a mechanism to file a counter notification that encourages the reinstatement of the material. ${ }^{66}$ The law does not require the service provider to reinstate the material, but instead strips the service provider of the safe harbor protection if it fails to do so. ${ }^{67}$ To retain the safe harbor protection, the potentially infringing material must be

Notification of Claimed Infringement (Nov. 28, 2011), available at http://www.copyright.gov/docs/onlinesp/comments/201 1/initial/verizon.pdf.

${ }^{62} 17$ U.S.C. $\$ 512$ (c)(3) (stating that to be effective, the notification must include the elements in this subsection).

${ }^{63}$ See discussion infra Part IV.

${ }^{64} 17$ U.S.C. § 512(d).

${ }^{65}$ See Thomas Catan, Con Artist Starred in Sting that Cost Google Millions, WALL ST. J., Jan. 25, 2012, at A1. The revenue was generated through Google's Adwords program. Id.

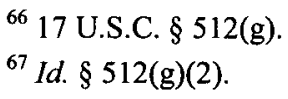


reinstated "not less than 10 , nor more than 14 , business days following receipt of the counter notice unless" the service provider is notified that a legal action has been filed. ${ }^{68}$ In this way, the notifying party has ten days to bring a legal action before the material is reinstated, but the posting party will be able to have the content reinstated within two weeks. ${ }^{69}$

The Electronic Frontier Foundation has created a simple, elegant letter that is generated through a browser-based checklist. ${ }^{70}$ Assuming a person seeking to file the counter-notice has selected each of the response boxes in the affirmative, the body of the text provides a nicely drafted response:

Please find attached to this letter a list of material removed by you pursuant to 17 U.S.C. Section 512 . I have a good faith belief that this material was removed or disabled in error as a result of mistake or misidentification of the material. I declare that this is true and accurate under penalty of perjury under the laws of the United States of America.

For purposes of this matter, I consent to the jurisdiction of the Federal District Court for the judicial district in which I reside. I also consent to service of process by the person providing notification under Section 512(c)(1)(C) or that person's agent. However, by this letter, I do not waive any other rights, including the ability to pursue an action for the removal or disabling of access to this material, if wrongful.

Having complied with the requirement of Section $512(\mathrm{~g})(3)$, I remind you that you must now replace the blocked or removed material and cease disabling access to it within fourteen business days of your receipt of this notice. Please notify me when this has been done ... ${ }^{71}$

${ }^{68} \mathrm{Id} . \S 512(\mathrm{~g})(2)(\mathrm{C})$.

${ }^{69} \mathrm{Id} . \S 512(\mathrm{~g})(2)$.

70 Counter-Notification, CHILLING EFFECTS, http://www.chillingeffects.org/dmca/ counter512.pdf (last visited Apr. 3, 2013).

${ }^{71} \mathrm{Id}$. To generate the form counter-notice, in which the quoted language appears, select each box on the webpage, input the applicable contact information, and click the "Generate Counter Notice" button. 
As noted in the draft response, the statement that "you must now replace" should be supplemented with, "or lose the safe harbor protections of 17 U.S.C. Section $512(\mathrm{~g})(1)$." Nonetheless, the letter provides a very nice, consumer-friendly tool for responding to overaggressive takedown requests.

\section{Current Rulemaking}

One of the problems plaguing the takedown notification system is the churn among the companies and the registered agents who are designated to receive the notices. ${ }^{72}$

The Copyright Office is proposing changes to the method of agent designation to make the system more efficient. ${ }^{73}$ As a result, the Copyright Office has proposed new rules for designating and updating electronic notice agents. ${ }^{74}$ The Copyright Office summarizes the process as follows:

\section{Designation of Online Service Provider Agent}

The Copyright Office is proposing to amend its regulations and practices governing the designation by online service providers of agents to receive notifications of claimed copyright infringement as provided for in section 512 of the Copyright Act. The Office intends to implement an electronic process by which service providers may designate agents to receive notifications of claimed infringement and an electronic database of designated agents of online service providers. In order to create the online database and to update the information currently maintained by the Copyright Office, it is proposed that all online service providers must file new designations of agents within one year after new regulations go into effect, and that thereafter all online service providers must update and/or verify the accuracy

${ }^{72}$ See Ellison v. Robertson, 357 F.3d 1072, 1080 (9th Cir. 2004) (holding that failure to forward e-mail from the first registered agent to the current active registered agent resulted in a loss of safe harbor protection).

${ }^{73}$ Designation of Agent to Receive Notification of Claimed Infringement, 76 Fed. Reg. 59,953 (Sept. 28, 2011) (to be codified at 37 C.F.R. pt. 201).

${ }^{74}$ Id. at $59,959-60$. 
of their information in the database at least once every two years. $^{75}$

The public comment period closed in late December $2011,{ }^{76}$ from which a general theme emerged. Commentators expressed concern that while an electronic database of the agents would be helpful to the public, the new system would generate a good deal of confusion and could result in the inadvertent loss of safe harbor protection. ${ }^{77}$ Failure to update one's agent in the new database, either initially or over time, would result in the automatic loss of the safe harbor protection. ${ }^{78}$ This risk would likely be much larger for smaller companies with only occasional user-generated content and rare contact with the takedown system. Because the proposal would strip a company of the safe harbor in the event of non-renewal even if the website information was correct, it could become a trap for the uninitiated. At the same time, however, the database would likely prove far more important for members of the public who are trying to provide a counter-notice, and it would add to the general transparency of the system.

While the Copyright Office is tinkering with the system, the modest scope of the proposed rulemaking also suggests a general acceptance of the current system. ${ }^{79}$ The Verizon comments and other complaints certainly show there are flaws in the system, but in the context of the billions of files uploaded and links shared, the system may achieve its compromise fairly effectively.

\section{Defamation AND HARMfUl SPEECH}

\section{A. Online Defamation Generally}

Online, there are many opportunities to be subject to a lawsuit for familiar claims like defamation. ${ }^{80}$ Liability for defamation, specifically

75 Rulemaking Proceedings, COPYRIGHT, http://www.copyright.gov/laws/ rulemaking.html (last updated Oct. 26, 2012).

${ }^{76}$ Designation of Agent to Receive Notification of Claimed Infringement, 76 Fed. Reg. at 59,953 .

${ }^{77}$ See Initial Comments on Proposed Rulemaking for Designation of Agents to Receive Notification of Claimed Infringement, COPYRIGHT, http://www.copyright.gov/docs/onlinesp/ comments/2011/initial/ (last visited Apr. 6, 2013).

${ }^{78}$ Designation of Agent to Receive Notification of Claimed Infringement, 76 Fed. Reg. at 59,959 .

${ }^{79}$ Id. at 59,954 .

${ }^{80} 2$ InTERnet Law AND Practice § 24:13 (2009). 
libel, is nothing new under the law. With the ubiquitous nature of the Internet as a news and social reporting tool, however, allegedly libelous statements can very quickly take on lives of their own. Online defamation lawsuits are following suit. For example, allegations of Twitter libel, known to some as "Twibel," are becoming commonplace, and the stakes can be high. ${ }^{81}$

While there are no defamation regulations in the United States for the online environment specifically, publishing any statement on Internetbased media-including websites, blogs, and social networking sites-can result in a defamation lawsuit. ${ }^{82}$ Although the First Amendment to the Constitution does afford protection for online discourse, defamation standards apply equally to the speaker in the online environment as in more traditional media. ${ }^{83}$ Speech concerning public officials and public figures is afforded heightened First Amendment protection in defamation law, ${ }^{84}$ and some states have applied a heightened standard to identify "John Doe" plaintiffs in defamation cases on First Amendment grounds. ${ }^{85}$ Otherwise,

${ }^{81}$ Kara Hansen Murphey, Defamation in 140 Characters or Less, PORTLAND TRIBUNE (Sept. 7, 2011, 5:00 PM), http://portlandtribune.com/component/content/article?id=11881. In 2011, singer Courtney Love paid fashion designer Dawn Simorangkir $\$ 430,000$ to settle Simorangkir's defamation lawsuit based on Love's allegedly libelous attacks in a series of tweets-and posts on MySpace and Etsy accounts-in 2009. Id. In addition, a Twitter libel case was filed in the Multnomah County Circuit Court in Oregon. Dr. Jerry Darm sued blogger Tiffany Craig for $\$ 1$ million based on Craig's comments on her Twitter account, @) tcraighenry, and her blog, Criminallyvulgar, through which she mentions Darm offered treatment for sex. Id.

${ }^{82}$ See, e.g., id.

${ }^{83}$ In re Anonymous Online Speakers, 661 F.3d 1168, 1173 (9th Cir. 2011).

${ }^{84}$ See Gertz v. Robert Welch, Inc., 418 U.S. 323, 327-28 (1974) (public figures may prevail in a libel action only if they prove that the defamatory statements were made with actual malice, whereas private figures need prove only negligence); New York Times Co. v. Sullivan, 376 U.S. 254, 279-80 (1964) (actual malice standard applies to public officials).

${ }^{85}$ States requiring a heightened standard to identify John Doe defendants include the following: Arizona, California, Connecticut, Maryland, Massachusetts, Nevada, New Jersey, New York, Pennsylvania, Tennessee, Texas, and the District of Columbia. For a discussion of the issue of free speech concerns with anonymous speech online, see Brian Hyer, Protecting John Doe: A New Standard for John Doe Subpoenas that Respects the Right to Speak Anonymously Online, 9 GEO. J. L. \& PUB. POL'Y 495 (2010). 
United States defamation standards in cyberspace are based on their offline counterparts. ${ }^{86}$

Internet content can theoretically be viewed globally, so it is important to consider online defamation laws that apply to potential plaintiffs in other parts of the world. For example, Australia's highest court found that Dow Jones, publisher of numerous periodicals, including the Wall Street Journal and Barron's, could be sued in Australia over an article that was written in the United States and distributed over the Internet. ${ }^{87}$ In addition, the United Kingdom currently is reviewing a draft "Defamation Bill" that was developed in March 2011 and is scheduled to be introduced in amended form to Parliament in May 2011. ${ }^{88}$ The United Kingdom's Defamation Bill specifically addresses online defamation. ${ }^{89}$

\section{B. Third-Party Limitations from the Communications Decency Act of 1996}

Where online defamation differs fundamentally from its physicalworld counterpart is in the area of secondary liability. Title $\mathrm{V}$ of the Telecommunications Act of 1996, more commonly known as the Communications Decency Act of 1996 (CDA), ${ }^{90}$ was promulgated in response to a growing concern surrounding online publication of pornography and other adult content. ${ }^{91}$ Furthermore, the CDA also applies to claims against online publishers of allegedly defamatory content. ${ }^{92}$ Section 230(c)(1) of the CDA states, "No provider or user of an interactive computer service shall be treated as the publisher or speaker of any information provided by another information content provider. ${ }^{, 93}$

\footnotetext{
${ }^{86}$ INTERNET LAW AND PRACTICE, supra note 80.

${ }^{87}$ See Dow Jones \& Co. v. Gutnick (2002) 210 CLR 575 (Austl.), available at
} $\mathrm{http}: / /$ www.austlii.edu.au/au/cases/cth/high_ct/2002/56.html.

${ }^{88}$ Ministry of Justice, Draft Defamation Bill: Consultation, 2011, Cm. 8020 (U.K.), available at http://www.justice.gov.uk/downloads/consultations/draft-defamationbill-consultation.pdf (the draft and consultation paper explaining its development).

${ }^{89} \mathrm{ld}$. at 3.

${ }^{90}$ Telecommunications Act of 1996 (Communications Decency Act), Pub. L. No. 104104 , tit. V, 110 Stat. $56,133-43$.

${ }^{91}$ Deborah Milham, The Constitutional Issues Presented by the Communications Decency Act's Application to HIV/AIDS Information on the Internet, 8 ALB. L.J. SCI. \& TECH. 195, 196 (1997).

92 See, e.g., Barnes v. YAHOO!, Inc., 570 F.3d 1096, 1102-03 (9th Cir. 2009).

${ }^{93} 47$ U.S.C. § 230(c)(1) (2006). 
This provision of the statute reversed the common law doctrine. The Restatement (Second) of Torts summarizes the common law rule: "Except as to those who only deliver or transmit defamation published by a third person, one who repeats or otherwise republishes defamatory matter is subject to liability as if he had originally published it." ${ }^{.94}$ Newspapers were of particular concern for reporting the libels of others:

Thus a newspaper is subject to liability if it republishes a defamatory statement, although it names the author and another newspaper in which the statement first appeared. The republication of a libel, being a separate publication, may make the second publisher liable although the original publisher is protected by a privilege. ${ }^{95}$

America Online, CompuServe, and other services were concerned that they had neither the knowledge nor capacity to respond to claims of defamation, and feared that such obligations would hobble the development of the nascent Internet; ${ }^{96}$ Congress agreed. ${ }^{97}$

\footnotetext{
${ }^{94}$ RESTATEMENT (SECOND) OF TORTS § 578 (1977).

${ }^{95} \mathrm{Id}$. $578 \mathrm{cmt}$. b.

${ }^{96}$ See generally Sewali K. Patel, Immunizing Internet Service Providers from ThirdParty Internet Defamation Claims: How Far Should Courts Go?, 55 VAND. L. REv. 647, 660-61 (2002).

${ }^{97}$ The House added $\S 230$ to the CDA to protect online service providers from thirdparty liability, and explained its policy for doing so:
}

It is the policy of the United States-

(1) to promote the continued development of the Internet and other interactive computer services and other interactive media;

(2) to preserve the vibrant and competitive free market that presently exists for the Internet and other interactive computer services, unfettered by Federal or State regulation;

(3) to encourage the development of technologies which maximize user control over what information is received by individuals, families, and schools who use the Internet and other interactive computer services;

(4) to remove disincentives for the development and utilization of blocking and filtering technologies that empower parents to restrict their children's access to objectionable or inappropriate online material; and 
In exchange, however, Congress sought "to encourage service providers to self-regulate the dissemination of offensive material over their services" 98 by removing risk of liability in instances where the service providers take steps to remove offensive content.

To provide this protection, $\S 230(\mathrm{c})(2)$ provides:

No provider or user of an interactive computer service shall be held liable on account of-

(A) any action voluntarily taken in good faith to restrict access to or availability of material that the provider or user considers to be obscene, lewd, lascivious, filthy, excessively violent, harassing, or otherwise objectionable, whether or not such material is constitutionally protected; or

(B) any action taken to enable or make available to information content providers or others the technical means to restrict access to material described in [subparagraph (A)]. ${ }^{99}$

The CDA therefore provides nearly blanket protection against liability for user-generated content stored on ISP servers. Service providers are immune from liability regardless of whether they attempt to remove potentially defamatory content. ${ }^{100}$ Computer mediated services have been developed to provide some hosts a measure of content moderating, but the method of monitoring has no impact on liability. ${ }^{101}$

Additionally, the protection for service providers is drafted broadly. The CDA defines "interactive computer service" as "any information service, system, or access software provider that provides or enables computer access by multiple users to a computer server, including specifically a service or system that provides access to the Internet and

(5) to ensure vigorous enforcement of Federal criminal laws to deter and punish trafficking in obscenity, stalking, and harassment by means of computer.

47 U.S.C. § 230(b) (2006).

${ }^{98}$ Zeran v. Am. Online, Inc., 129 F.3d 327, 331 (4th Cir. 1997).

${ }^{99} 47$ U.S.C. $\$ 230$ (c)(2).

${ }^{100}$ See Batzel v. Smith, 333 F.3d 1018, 1037 (9th Cir. 2003).

101 Melissa A. Troiano, The New Journalism? Why Traditional Defamation Laws Should Apply to Internet Blogs, 55 AM. U. L. REv. 1447, 1469-70 (2006). 
such systems operated or services offered by libraries or educational institutions," and "information content provider" as "any person or entity that is responsible, in whole or in part, for the creation or development of information provided through the Internet or any other interactive computer service." 102

Most importantly, unlike the duties to address potential copyright issues, the protection for ISPs under the CDA has no takedown obligations, no requirement that the ISP accept notice of potential third-party liability, and no obligation to respond to a complaint of defamation. ${ }^{103}$ Courts have interpreted $\S 230$ to relieve ISPs of liability for the defamatory nature of information published by their users. ${ }^{104}$ In most instances, ISPs are not considered legally responsible for the harm caused by information that their users publish online. ${ }^{105}$ This result is consistent with the traditional off-line requirement that a media defendant in a defamation suit must be found to have some degree of fault in publishing allegedly defamatory statements. ${ }^{106}$

\section{Responses to Harmful Speech}

Notwithstanding the broad statement of immunity, there may be a number of techniques for addressing defamatory material on the Internet.

${ }^{102} 47$ U.S.C. $\S 230(f)(2)-(3)$.

${ }^{103}$ See Austin v. Crystaltech Web Hosting, 125 P.3d 389, 393-94 (Ariz. Ct. App. 2005) (explaining that the CDA immunized the web hosting company from liability for hosting a third party's website that allegedly contained defamatory statements about plaintiff despite the web hosting company having received notice regarding the defamatory nature of the content it was hosting).

104 See, e.g., Batzel, 333 F.3d at 1029 (declaring that an operator of a listserv and website is a user of interactive computer services, entitling CDA protection from liability for publishing information provided by another information provider); Barrett v. Rosenthal, 146 P.3d 510, 513 (Cal. 2006) (ruling that $\S 230$ immunized defendant from liability for republishing an allegedly defamatory article authored by a third party, effectively establishing that "distributors" or "secondary publishers" are entitled to the same broad immunity afforded to publishers under the CDA).

${ }^{105} 47$ U.S.C. $\$ 230$ (c)(1) ("No provider or user of an interactive computer service shall be treated as the publisher or speaker of any information provided by another information content provider.").

${ }^{106}$ See Gertz v. Robert Welch, Inc., 418 U.S. 323, 347-48 (1974) (establishing that a private figure who brings a suit for defamation cannot recover without some showing that the media defendant was at fault in publishing the statements at issue). 
Most obviously, the inability to bring an action or a notice against ISPs does not immunize parties who have posted defamatory material. ${ }^{107}$ Therefore, legal action often begins with a "cease and desist" letter demanding takedown of the offending published language. ${ }^{108}$ Sharing this information with ISPs and asking for relief may result in some response. As noted, ISPs are immunized from liability regardless of whether they choose to respond. ${ }^{109}$

Depending on the nature of the content in question, there may also be relief under cyberstalking or cyberbullying laws. "Many states have enacted 'cyberstalking' or 'cyberharassment' laws or have laws that explicitly include electronic forms of communication within more traditional stalking or harassment laws. In addition, recent concerns about protecting minors from online bullying or harassment have led states to enact 'cyberbullying' laws." 10 To the extent the offensive speech constitutes harassment under the state law definition, there are state statutory remedies authorizing the removal of content and the arrest of parties responsible for posting such content. ${ }^{11}$

Similarly, if the offensive content includes protected informationincluding driver's license information, social security numbers, credit card data, health data, or protected financial information - the various state and federal privacy laws can be used to force the removal of the content. ${ }^{112}$ Generally, laws that emphasize liability for disclosure do not limit their liability to "speakers" or "publishers"; failure of ISPs to remove protected information could give rise to direct liability, rather than mere secondary liability as a republisher of the user-generated content. ${ }^{113}$

\footnotetext{
${ }^{107}$ See Barrett, 146 P.3d at 513.

${ }^{108}$ E.g., Online Policy Grp. v. Diebold, Inc., 337 F. Supp. 2d 1195, 1198 (N.D. Cal. 2004).

${ }^{109}$ See Ryan Dube, How to Remove False Information About Yourself on Internet, MAKEUSEOF (Jan. 16, 2009), http://www.makeuseof.com/tag/how-to-remove-false-libelousinformation-about-yourself-online/.

${ }^{110}$ State Cyberstalking and Cyberharassment Laws, NAT'L CONF. ST. LEGISLATURES (Nov. 16, 2012), http://www.ncsl.org/issues-research/telecommunications-informationtechnology/cyberstalking-cyberharassment-and-cyberbullying-l.aspx.

111 See, e.g., IOWA CODE ANN. $§ 708.7$ (West 2003); WASH. REV. CODE $\S 9.61 .260$ (2010).

${ }^{112}$ See, e.g., 15 U.S.C. § 6801 (2006); OHIO REV. CODE ANN. § 1347.10 (West 2004).

${ }^{113}$ See Matthew Schruers, The History and Economics of ISP Liability for Third Party Content, 88 VA. L. REv. 205, 211 (2002).
} 
Despite the limitations on copyright causes of action, copyright remains a more effective tool for curbing harmful speech online. Copyright has an express notice-and-takedown mechanism: Any allegations that the offensive content was copyrighted material-such as photographs or unauthorized re-postings of the target's work-need only meet the requirements discussed previously to trigger a mandatory takedown. Of course, the good faith belief that the materials are the copyrighted works of the complainant must be met, ${ }^{114}$ but in many such disputes, the defaming poster has employed copyrighted material subject to a takedown notice. This protection, however, can be abused. The firm Medical Justice Inc. had created a "'vaccine against libel,' a set of contracts providing authority to doctors over online comments posted by patients." 15 The control was a provision granting the doctors exclusive copyright in any comments or posts about the health care provider. ${ }^{116}$ The all-too-clever contract sparked a class action lawsuit, and shortly thereafter, was retired. ${ }^{117}$

According to a report of the class action lawsuit, a New York Dentist issued the following promise:

[She] promise[d] not to evade HIPAA's patient privacy protection in return for patients' commitment not to disparage her, not to post any comments about her publicly; if the patient writes anything about the dentist, the patient assigns the copyright in those comments to [Dentist Stacy Makhnevich]. Relying on the form, Makhnevich sent one of her patients invoices purporting to bill him a daily hundred-dollar fine for having posted comments about her on Internet review web sites. ${ }^{18}$

${ }^{114} 17$ U.S.C. $\$ 512(\mathrm{c})(3)(\mathrm{A})(\mathrm{v})(2006)$.

${ }^{115}$ Alicia Gallegos, Company Withdraws Contracts Controlling Online Comments by Patients, AM. MED. News (Jan. 2, 2012), http://www.ama-assn.org/amednews/2012/01/02/ prsa0102.htm.

${ }^{116} \mathrm{Id}$.

${ }^{117}$ Id. See also Paul Alan Levy, Medical Injustice - Contracts that Suppress Patient Comments About Their Doctors or Dentists, Public Citizen (Nov. 30, 2011), http://pubcit.typepad.com/clpblog/2011/11/medical-injustice-contracts-that-suppresspatient-comments-about-their-doctors-or-dentists.html.

${ }^{118}$ Levy, supra note 117. 
The class action lawsuit will undoubtedly highlight the various ethical and professional lapses of the vaccinating agreement. At the outset, if the report is accurate, then the exchange of the legal HIPAA duty cannot even serve as consideration for the transfer of copyright, so the agreement fails to be a valid contract for lack of consideration. ${ }^{119}$ While transfer of copyright has been upheld in videogame end user license agreements, this has been in the context of the consumer receiving a license to use the game to generate copyrightable content within the game as part of the gameplay. ${ }^{120}$ In the absence of any consumer or public health benefit, the transfer of exclusive rights as a condition of medical services could, and should, be deemed unconscionable. ${ }^{121}$ Moreover, because this is a copyright case, the prevailing party may be entitled to attorneys' fees. ${ }^{122}$ This embarrassing and improvident use of an overly aggressive policing technique should provide a solid reminder of the importance for restraint in policing harmful speech.

Instead, once content that is "bad" but not infringing, defamatory, or invasive of privacy appears online, the better strategy is to mitigate the damage by relying on the rapid staleness of Internet content. Most readers will find such unwanted content through searching. The unwanted content cannot be removed, but it can be pushed down to the latter pages of a search by publishing relevant, positive content that is trafficked and crosslinked. ${ }^{123}$ Many services promise such resources. ${ }^{124}$ This Article cannot address the effectiveness of such techniques, but they are far better than the secondary damage one can do to a reputation by unwarranted over-

119 See White v. Vill. of Homewood, 628 N.E.2d 616, 619 (Ill. Ct. App. 1993) ("Consideration cannot flow from an act performed pursuant to a pre-existing legal duty."); RESTATEMENT (SECOND) OF CONTRACTS $§ 73$ (1981) ("Performance of a legal duty owed to a promisor which is neither doubtful nor the subject of honest dispute is not consideration; but a similar performance is consideration if it differs from what was required by the duty in a way which reflects more than a pretense of bargain.").

${ }^{120}$ See, e.g., Davidson \& Assocs. v. Jung, 422 F.3d 630, 639 (8th Cir. 2005); ProCD, Inc. v. Zeidenberg, 86 F.3d 1447, 1448-49 (7th Cir. 1996); see also Mark A. Lemley, Intellectual Property and Shrinkwrap Licenses, 68 S. CAL. L. Rev. 1239, 1241 (1995).

${ }^{121}$ See, e.g., Bragg v. Linden Research, Inc., 487 F. Supp. 2d 593 (E.D. Pa. 2007).

${ }^{122} 17$ U.S.C. $\$ 505$ (2006).

123 Online Reputation Management Services, RANDOM BYTE, http://www.randombyte.com/online-reputation-management-services/ (last visited Feb. 22, 2013).

$$
{ }^{124} \text { E.g., id. }
$$


aggressive policing. As with any countermeasure, a moderated and proportionate response remains the key.

\section{TRADEMARK}

Unlike the copyright system, which provides for a notice-andtakedown mechanism, trademark owners are left with a much more ambiguous and ill-defined set of steps to take. The only statutory protection for trademarks tailored to the online environment has come in the form of domain name protection. ${ }^{125}$

In the absence of any specifically tailored statutory response, the Lanham Act ${ }^{126}$ is interpreted to address the role of trademarks in the online environment. In most instances, this is done by assessing whether the trademark in question was a registered mark ${ }^{127}$ or was protected from unfair competition, ${ }^{128}$ the strength of mark, ${ }^{129}$ and the various factors that suggest a likelihood of confusion between the plaintiff's mark and defendant's mark. ${ }^{130}$

As applied online, many of the same issues regarding likelihood of confusion take on new meaning. Counterfeiting is a serious problem for

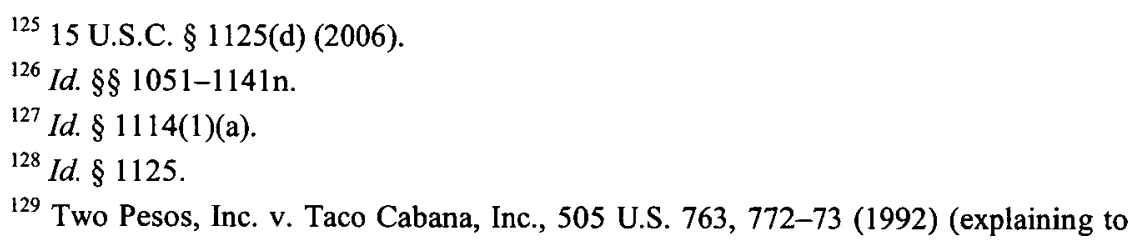
be treated as a trademark, the symbol in question must be distinctive either because it is inherently distinctive or because it has acquired secondary meaning as a source identifier). See also Abercrombie \& Fitch Co. v. Hunting World, Inc., 537 F.2d 4, 9-11 (2d Cir. 1976).

${ }^{130}$ AMF, Inc. v. Sleekcraft Boats, 599 F.2d 341, 348-49 (9th Cir. 1979). To determine the likelihood of confusion, a number of factors are weighed. For example, the following are the Sleekcraft factors:

1. strength of the mark; 2 . proximity of the goods; 3 . similarity of the marks; 4. evidence of actual confusion; 5 . marketing channels used; 6. type of goods and the degree of care likely to be exercised by the purchaser; 7. Defendant's intent in selecting the mark; and 8. likelihood of expansion of the product lines.

Id. Each Circuit has its own set of similar factors, described slightly differently. See, e.g., Century 21 Real Estate Corp. v. Lendingtree, Inc., 425 F.3d 211, 224 (3d Cir. 2005); Henri's Food Prod. Co. v. Kraft Inc., 717 F.2d 352, 354 (7th Cir. 1983); Beer Nuts. Inc. v. Clover Club Foods Co., 711 F.2d 934, 940 (10th Cir. 1983). 
owners of popular products, and using the Internet to sell counterfeit goods does not significantly change the law or its application. ${ }^{131}$ For trademarks that are not federally registered, protection only applies to the geographic area in which the mark is exploited. ${ }^{132}$ Nonetheless, because the Internet has no geographic limitations, this can give rise to additional conflicts between remote users and create consumer confusion where none had previously existed. ${ }^{133}$

\section{A. Trademarks and Internet Speech}

There remains a great deal of confusion among the public and even the courts regarding the use of trademarks by bloggers, Twitter users, social media enthusiasts, and others. ${ }^{134}$ The Citizen Media Law Project sums up the situation quite elegantly:

The good news is that courts have consistently protected the public's right to use the trademarks of others in order to engage in criticism, commentary, news reporting and other forms of noncommercial expression. As long as what you're doing is really commentary, criticism, or reporting (etc.), and not a surreptitious attempt to sell goods or services, or to deceptively attract customers or readers you otherwise would not have had, you should be able to defeat a trademark claim brought against you. The bad news is that the law relating to this intersection of trademark law and free expression is complex and confusing. Neither Congress nor the courts have developed a simple and clear rule that protects your rights to use the trademarks of others for free speech purposes; instead they've developed a complex array of defenses to

${ }^{131} 15$ U.S.C. $\S 1127$ (“A 'counterfeit' is a spurious mark which is identical with, or substantially indistinguishable from, a registered mark.").

${ }^{132}$ See David S. Barrett, The Future of the Concurrent Use of Trademarks Doctrine in the Information Age, 23 HASTINGS COMM. \& ENT. L.J. 687, 692-93 (2001).

${ }^{133}$ Id. at $689,703$.

${ }^{134}$ See generally William McGeveran, Four Free Speech Goals for Trademark Law, 18 Fordham INTELl. Prop. MEDiA \& ENT. L.J. 1205 (2008). 
trademark claims that even lawyers find difficult to untangle. ${ }^{135}$

What should be the threshold issue is often left until far too late in the analysis, namely whether the unauthorized user of the trademark is making a commercial use of the mark. ${ }^{136}$ This approach has had limited judicial support. ${ }^{137}$ Unfortunately, courts seem to treat any links to advertising or income as a commercial use-an approach that would render newspapers subject to commercial speech standards because of the advertisements they run. ${ }^{138}$ Over time, this Internet exceptionalism will erode, but for now, other approaches are necessary to explain what a speaker can do with the trademark of another.

As presently interpreted, the notion of commercial use typically involves using trademarks in parodies. ${ }^{139}$

The courts have adopted different ways of incorporating such First Amendment interests into the analysis. For example, some courts have applied the general "likelihood of confusion" analysis, using the First Amendment as a factor in the analysis. Other courts have expressly balanced First Amendment considerations against the degree of likely confusion. Still other courts have held that the First Amendment effectively trumps

135 Using the Trademarks of Others, Citizens MEdia LAw Project, http://www.citmedialaw.org/legal-guide/using-trademarks-others (last visited Feb. 22, 2013).

${ }^{136}$ See, e.g., FieldTurf, Inc. v. Triexe Mgmt. Grp., Inc., No. 03 C 5704, 2003 U.S. Dist. LEXIS 22280, at *3-4 (N.D. Ill. Dec. 11, 2003) ("The trademark infringement statute, 15 U.S.C. $\S 1114(1)(a)$, the unfair competition statute, 15 U.S.C. $\S 1125(\mathrm{a})$, and the trademark dilution statute, 15 U.S.C. $\S 1125(\mathrm{c})$, all require the trademark owner to demonstrate that the defendant used the mark in commerce.").

${ }^{137}$ Compare Bosley Med. Inst., Inc. v. Kremer, 403 F.3d 672, 678 (9th Cir. 2005) (finding no commercial use on gripe site that had no advertising or links to commercial sites), with Taubman Co. v. Webfeats, 319 F.3d 770, 775 (6th Cir. 2003) (finding commercial use was supported by a link on one of the defendant's site to the defendant girlfriend's shirt business).

${ }^{138}$ See Using the Trademarks of Others, supra note 135.

139 Overview of Trademark Law, HARVARD LAw, http://cyber.law.harvard.edu/ metaschool/fisher/domain/tm.htm (last visited Feb. 22, 2013) ("[C]ertain parodies of trademarks may be permissible if they are not too directly tied to commercial use."). 
trademark law, under certain circumstances. In general, however, the courts appear to be more sympathetic to the extent that parodies are less commercial, and less sympathetic to the extent that parodies involve commercial use of the mark. ${ }^{140}$

A more practical analysis would recognize that the Muppet character, Spa'am, was not a commercial use of the Hormel trademark; ${ }^{141}$ the "Enjoy Cocaine" poster featuring the trademark and trade dress of the Enjoy Coke trademark was not a competitive product; ${ }^{142}$ and a titillating parody of an L.L. Bean advertisement was not an actual advertisement. ${ }^{143}$

Beyond noncommercial use and its parody counterpart, there are two types of fair use. The first type is nominative fair use, under which the trademark can be used when it is used correctly, without creating consumer confusion as to the actual source of the mark. ${ }^{144}$ Nominative use includes the right to identify the trademarks of goods and services in reviews, critiques, and even competitive advertisements. ${ }^{145}$ The owner of a trademark cannot thwart bad press merely by claiming ownership of the product's name. ${ }^{146}$

The second type of fair use involves traditional fair use in which a word, though it may be a trademark in some contexts, is used for its ordinary meaning. ${ }^{147}$ No one, for example, would expect the maker of iPads to stop a grocery store from advertising Apples - even if the word were capitalized. The word used in its ordinary context has no trademark value. Similarly, the use of the phrase "fish fry" cannot infringe the trademark "Fish-Fri" when used to describe the purpose of the product. ${ }^{148}$

${ }^{140} I d$.

${ }^{141}$ Hormel Foods Corp. v. Jim Henson Prods., Inc., 73 F.3d 497, 500 (2d Cir. 1996).

${ }^{142}$ Coca-Cola Co. v. Gemini Rising, Inc., 346 F. Supp. 1183, 1186 (E.D.N.Y. 1972).

${ }^{143}$ L.L. Bean, Inc. v. Drake Publishers, Inc., 811 F.2d 26, 27-28 (1st Cir. 1987).

144 Toyota Motor Sales, U.S.A., Inc. v. Tabari, 610 F.3d 1171, 1175-76 (9th Cir. 2010); New Kids on the Block v. News Am. Publ'g, Inc., 971 F.2d 302, 308 (9th Cir. 1992).

${ }^{145}$ See New Kids on the Block, 971 F.2d at 306.

${ }^{146}$ Brother Records, Inc. v. Jardine, 318 F.3d 900, 908 (9th Cir. 2003); Downing v. Abercrombie \& Fitch, 265 F.3d 994, 1009 (9th Cir. 2001); Volkswagenwerk Aktiengesellschaft v. Church, 411 F.2d 350, 352 (9th Cir. 1969).

${ }^{147}$ Zatarains, Inc. v. Oak Grove Smokehouse, Inc., 698 F.2d 786, 791 (5th Cir. 1983).

${ }^{148}$ Id. at 792. See also KP Permanent Make-Up, Inc. v. Lasting Impression I, Inc., 543 U.S. 111, 122 (2004) (holding that some possibility of consumer confusion about the origin of goods or services affected was compatible with fair use). 
Using a trademark with a link to its competitor's website, misrepresenting endorsements, or otherwise misleading the public (other than self-evident parody) raises issues of actionable consumer confusion or unfair competition. ${ }^{149}$ As a result, everyone who posts or tweets must ask themselves both whether they are using a trademark and whether the use is misleading. A misleading use is not protected as a fair use. ${ }^{150}$ If the trademark claim is more accurately a claim for product disparagement, then the earlier discussion of defamation is the more applicable standard. ${ }^{151}$

B. Early Commercial Battles-Links, Frames, Domains, and Metatags

\section{Linking}

Among business competitors, the issues of trademark infringement are of far more significant concern. Linking has never been considered a copyright violation because the link merely provides access to the copyright owner's own material. ${ }^{152}$ The URL in the link is a fact, an address that cannot be protected by copyright. ${ }^{153}$

There has been some concern that deep linking-creating the hypertext

${ }^{149}$ See Soilworks, LLC v. Midwest Indus. Supply, Inc., 575 F. Supp. 2d 1118, 1129-30 (D. Ariz. 2008).

${ }^{150} \mathrm{Id}$. at 1130 . Use in a fictional work or parody is likely not to be treated by the reader or viewer as factual, so it is far less likely to be misleading. Nonetheless, even fictional works are sometimes the subject of litigation for misrepresenting a product as dangerous. See Campbell v. Acuff-Rose Music, Inc., 510 U.S. 569, 583 (1994).

${ }^{151}$ See discussion supra Part III.

152 See Metro-Goldwyn-Mayer Studios Inc. v. Grokster, Ltd., 545 U.S. 913, 937-38 (2005). Links to infringing content can result in contributory liability if the standards for culpability are met. Id. at 937.

${ }^{153}$ Ticketmaster Corp. v. Tickets.Com, Inc., No. CV 99-7654 HLH(BQRX), 2000 WL 525390 , at $* 2$ (C.D. Cal. Mar. 27, 2000). The court explained:

Further, hyperlinking does not itself involve a violation of the Copyright Act (whatever it may do for other claims) since no copying is involved, the customer is automatically transferred to the particular genuine web page of the original author. There is no deception in what is happening. This is analogous to using a library's card index to get reference to particular items, albeit faster and more efficiently.

Id. See also Shaw v. Lindheim, 919 F.2d 1353, 1356 (9th Cir. 1990) (citing Narell v. Freeman 872 F.2d 907, 910 (9th Cir. 1989)) ("Copyright law protects an author's expression; facts and ideas within a work are not protected."). 
links to pages other than the homepage of a site-could create additional legal liability. ${ }^{154}$ However, this practice has become ubiquitous, largely causing this concern to disappear. Internet sites have responded by moving their ads to the pages with the popular content. ${ }^{155}$ Citizen Media Law Project notes, "No court has ever found that deep linking to another website constitutes copyright or trademark infringement.... Therefore, you can link to other websites without serious concerns about legal liability for the link itself, with the exception of activities that might be contributory copyright infringement ...."156

Breach of contract may be the one remaining basis for liability. Particularly if the site is protected by software that requires a clickwrap agreement so that anyone who uses the site must begin by reviewing and agreeing to those terms, then deep linking past the clickwrap might be a breach of the agreement. ${ }^{157}$ Moreover, depending on the technology designed to assure compliance with the clickwrap, the strategy to deep link could reveal a breach of the anticircumvention provisions of the DMCA. ${ }^{158}$

From a trademark perspective, the other linking concern is the extent to which the design of the first page and the use of the links can create a false impression as to the source of the content, advertisements, and goods on the linked pages. ${ }^{159}$ The test remains one of consumer confusion, but a clever design might suggest that the defendant's site is actually a component of the plaintiff's site and use this confusion to redirect consumers and business. ${ }^{160}$ Such confusion and redirection through the use of website design and deep links would undoubtedly be actionable. ${ }^{161}$

154 Linking to Copyrighted Materials, Citizen MEdIA LAW ProJECT, http://www.citmedialaw.org/legal-guide/linking-copyrighted-materials (last visited Feb. 22, 2013).

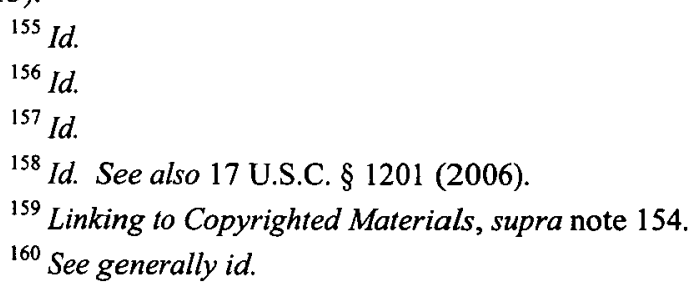

${ }^{161}$ Id. Consider a counterfeiting website that copied the links to its target's privacy policy, contact pages and other footer pages. Such activities would violate the anticounterfeiting provisions of the Lanham Act, particularly if the counterfeiting site mirrored or linked to products of the target site and then directed customers to its own shopping cart. See Frank C. Gomez, Note, Copyright: Preemption: Misappropriation: Washington Post v. Total News, Inc., 13 BERKELEY TECH. L.J. 21, 22 (1998). 


\section{Framing}

A variation of this technique is known as framing. "Framing enables a Web page designer to split a page into independent scrollable regions, ... . [T] he framing feature allows a user to 'display' a portion of a separate Web site on the one originally accessed." 162 Because framing intentionally blurs the source of the content between the various sites, the unauthorized use of a third party's framed content is potentially more likely to lead to consumer confusion and therefore trademark liability. As Citizens Media Law Project notes, "Depending on how you design your page, a user might be confused into believing that all of the source material is yours. Some plaintiffs have sued websites for framing under trademark and related areas of law, but most cases have settled and the law remains unclear." 163

Despite the lack of reported decisions, the leading controversy involved Total News, which created frames but then displayed the content of other publishers including the Washington Post. ${ }^{164}$ To the extent such frames hide the actual trademarks of the content providers or associate Total News trademarks with content that it did not create, the frames created a likelihood of confusion as to the source of the content, which it exploited by selling advertising on its site. ${ }^{165}$ The case was ultimately settled. ${ }^{166}$

\section{Domains}

To the dismay of trademark holders, even the domain name of a company may not automatically create consumer confusion. ${ }^{167}$ Cybersquatting requires "bad faith intent to profit from that mark."168

${ }^{162}$ Gomez, supra note 161, at 22.

${ }^{163}$ Linking to Copyrighted Materials, supra note 154.

${ }^{164}$ See Complaint, Washington Post Co. v. Total News, Inc., No. 97 Civ. 1190 (S.D.N.Y. 1997), 1997 WL 33633041.

${ }^{165}$ Id. ๆ 52.

${ }^{166}$ Nicole M. Bond, Linking and Framing on the Internet: Liability Under Trademark and Copyright Law, 11 DePAul Bus. L.J. 185, 196 (1998). Under the terms of the settlement agreement, Total News agreed to remove its frames, but retained the right to link to the plaintiff's news content. Id.

${ }^{167} 15$ U.S.C. $\S 1125$ (d) (2006).

${ }^{168}$ The Lanham Act provides the following on cyberpiracy prevention: 
Some words-such as apple, diamond, or Hyatt-represent different trademark owners in non-overlapping industries. There simply is no right for one of those owners to have rights over the dot-com version of the domain. No user will be able to demonstrate a bad faith use by the other parties with a reasonable purpose for using the domain.

In other situations, using a trademark as part of a longer domain may also represent nominative fair use. The "sucks" sites that integrate the corporate trade name and the sucks appellation are unlikely to confuse the public regarding the source of the site critical to ownership.

Similarly, sites that do not confuse the public can use the trademark in a nominative fashion. As one court explained:

You can preen about your Mercedes at mercedesforum.com and mercedestalk.net, read the latest about your double-skim-no-whip latte at starbucksgossip.com and find out what goodies the world's greatest electronics store has on sale this week at fryselectronics-ads.com. Consumers who use the internet for shopping are generally quite sophisticated about such matters and won't be fooled into thinking that the prestigious German car manufacturer sells boots at mercedesboots.com, or homes at mercedeshomes.com, or that comcastsucks.org is sponsored or endorsed by the TV

A person shall be liable in a civil action by the owner of a mark, including a personal name which is protected as a mark under this section, if, without regard to the goods or services of the parties, that person-

(i) has a bad faith intent to profit from that mark, including a personal name which is protected as a mark under this section; and

(ii) registers, traffics in, or uses a domain name that-

(I) in the case of a mark that is distinctive at the time of registration of the domain name, is identical or confusingly similar to that mark; (II) in the case of a famous mark that is famous at the time of registration of the domain name, is identical or confusingly similar to or dilutive of that mark; or (III) is a trademark, word, or name protected by reason of section 706 of title 18 or section 220506 of title 36 .

Id. $\S 1125(\mathrm{~d})(1)(\mathrm{A})$. 
cable company just because the string of letters making up its trademark appears in the domain. ${ }^{169}$

\section{Metatags}

Prior to the ascendance of the Google algorithm that ranks pages based on relevance, ${ }^{170}$ a primary ranking tool was the text on a site and the metatags encoded into a site. ${ }^{171}$ "A metatag is a part of a Web site that is not seen by the public, but is read by search engine web browsers and later used by the browsers to classify the Web site."172 Although hidden text and metatags may play lesser roles in page rankings, they still affect the ability of a search engine to find a particular page in response to a query. ${ }^{173}$ "Metatags are used to increase the probability that a Web site will be seen by a customer who has typed a particular search query into his or her search engine." 174

Metatags are essential for the public to find content on the Internet. ${ }^{175}$ When these cases were first litigated, there was a tendency to assume any use of another's domain name or metatag was likely to cause confusion:

When a firm uses a competitor's trademark in the domain name of its web site, users are likely to be confused as to its source or sponsorship. Similarly, using a competitor's trademark in the metatags of such web site is likely to cause what we have described as initial interest

${ }^{169}$ Toyota Motor Sales, U.S.A., Inc. v. Tabari, 610 F.3d 1171, 1178 (9th Cir. 2010).

${ }^{170}$ See Jon M. Garon, Searching Inside Google: Cases, Controversies and the Future of the World's Most Provocative Company, 30 Loyola L.A. ENT. L. Rev. 429, 431 (2010).

${ }^{171}$ See generally id. at 430-31 (explaining how Google continues to use text-matching techniques in addition to its PageRank software).

${ }^{172}$ Australian Gold, Inc. v. Hatfield, 436 F.3d 1228, 1233 n.3 (10th Cir. 2006).

${ }^{173}$ See Garon, supra note 170 , at 430-31.

${ }^{174}$ Hatfield, 436 F.3d at 1233 n.3.

${ }^{175}$ See J. ThOMAS MCCARTHY, MCCARTHY ON TRADEMARKS AND UNFAIR COMPETITION $\S 25: 69$ (4th ed. 2012) ("Search engines in the early days of the Internet relied heavily on metatags to find Web sites. However, modern search engines no longer use Metatags."); HTML Metatags, ЕсноЕсно.сом, http://www.echoecho.com/htmlmetatags01.htm (last visited Feb. 22, 2013) (explaining the differences between keyword and description metatags and their prospective usefulness). 
confusion. These forms of confusion are exactly what the trademark laws are designed to prevent. ${ }^{176}$

In the ensuing years, however, the public's reliance on domain names and metatags has diminished and the courts' expectations of the reasonable consumer have increased. ${ }^{177}$ Today, when used accurately, metatags can represent nominative fair use, accurately listing products or services of a company. ${ }^{178}$ From the broader context of the website, the consumers understand when a third party is selling a product lawfully, but without authorization. Retailers can list the names of the products on their websites and in the metatags enabling search engines without the permission of the manufacturers. When instead the metatags are used as part of a larger effort to create consumer confusion, however, the invisible nature of the metatag will not shield its user from creating consumer confusion and trademark infringement. ${ }^{179}$

In sum, the old battles of linking, framing, domain names, and metatags have comfortably resolved back into the traditional notions of likelihood of consumer confusion. Courts distinguish nominative and descriptive use of terms from the misuse of terms and marks likely to create consumer confusion, just as they have outside the Internet for many decades.

\section{New Battles-Keyword Advertising}

Just as the trademark disputes over frames and metatags reflected the tension between business owners to define fair competition, the current controversy focuses on the importance of "search" as the primary method

${ }^{176}$ Brookfield Commc'ns v. W. Coast Entm't Corp., 174 F.3d 1036, 1066 (9th Cir. 1999).

${ }^{177}$ Network Automation, Inc. v. Advanced Sys. Concepts, Inc., 638 F.3d 1137, $1153-$ 54 (9th Cir. 2011) (reversing the lower court because they used too low a standard for the expectations of the modern reasonable consumer, and applying as another relevant factor the difference between domain name and keyword search confusion).

${ }^{178}$ See Hatfield, 436 F.3d at 1239 (stating defendant's listing of plaintiff's trademarks in defendant's metatags constituted initial confusion); Faegre \& Benson, LLP v. Purdy, 367 F. Supp. 2d 1238, 1247 (D. Minn. 2005) ("Based on the fair use defense ... Purdy can legally use Faegre's marks in his metatags in the descriptive sense . . . however, he is not permitted to use Faegre's marks in his metatags in order to divert internet users from Faegre's web site.").

${ }^{179}$ Hatfield, 436 F.3d at 1239-40. See also Brookfield, 174 F.3d at 1063 (analogizing non-internet interest confusion with internet-based interest confusion). 
of finding online content. Consumers typically use the search function in their browser, tablet, or smartphone to find online content rather than relying on hundreds or thousands of bookmarks and hot links. ${ }^{180}$ Google's AdWords is the largest such program. ${ }^{181}$ Advertising revenue-much of it from AdWords-accounts for $97 \%$ of Google's revenue: ${ }^{182}$

AdWords is Google's program through which advertisers purchase terms (or keywords). When entered as a search term, the keyword triggers the appearance of the advertiser's ad and link. An advertiser's purchase of a particular term causes the advertiser's ad and link to be displayed on the user's screen whenever a searcher launches a Google search based on the purchased search term. Advertisers pay Google based on the number of times Internet users "click" on the advertisement, so as to link to the advertiser's website. ${ }^{183}$

Microsoft's Bing provides a similar service. ${ }^{184}$

As the debate over keyword advertising moved through the courts, the initial question was whether the purchase of a keyword-absent the word's

${ }^{180}$ See Rescuecom Corp. v. Google Inc., 562 F.3d 123, 125 (discussing Google's search function and its utility to users); Vitality Friedman, Google PageRank: What Do We Know About It?, SMASHING MAG. (June 5, 2007), http://www.smashingmagazine.com/2007/06/05/ google-pagerank-what-do-we-really-know-about-it/ (stating that Google's search function "helps keep our search clean and efficient"); Eric Siu, 24 Eye-Popping SEO Statistics, SEARCH ENGINE J. (Apr. 19, 2012), http://www.searchenginejournal.com/24-eye-poppingseo-statistics/42665/ (" $93 \%$ of online experiences begin with a search engine . . 82.6\% of internet users use search.”).

${ }^{181}$ Regina Nelson Eng, A Likelihood of Infringement: The Purchase and Sale of Trademarks As Adwords, 18 ALB. L.J. SCI. \& TECH. 493, 495 (2008) ("With access to over eighty-six percent of internet users, Google's flagship advertising program, AdWords, is one of the most powerful resources for internet advertisers, as well as Google's highest revenue source.").

${ }^{182}$ Garon, supra note 170 , at 432 .

${ }^{183}$ Rescuecom, 562 F.3d at 125.

${ }^{184}$ Bing Ads, MiCrosofT, http://advertise.bingads.microsoft.com/en-us/bing-ads-howit-works?s_cid=us_smb_a_web_bing_footer (last visited Feb. 22, 2013). 
appearance on the search engine-constituted a use in commerce. ${ }^{185}$ This debate was reminiscent of the early discussion of metatags because the words themselves were not read by the consumer but instead led the software to present different content. Originally, the Ninth Circuit "assumed, without expressly deciding, that the use of a trademark as a search engine keyword that triggers the display of a competitor's advertisement is a 'use in commerce' under the Lanham Act." 186 The Second Circuit struggled more with the concept, but in a very thoughtful opinion, answered the question in the affirmative ${ }^{187}$ and seemed to lay the question to rest. ${ }^{188}$

Determining that the keyword is a use in commerce constitutes only the threshold question regarding the likelihood of consumer confusion. For the search engine companies and intermediaries, the probable result is that they cannot be found to be creating consumer confusion with their customers advertising so long as they continue to clearly distinguish between advertisements based upon the keyword entries and the actual results of their algorithms. The separation between ads and indexed searches is a business choice that is presently being made by Google, Microsoft (owner of Bing), and the companies that license their search services. ${ }^{189}$ Nothing in the architecture of the search algorithm requires this separation..$^{190}$ On the other hand, the concern over trademark liability and consumer backlash at the potential confusion is likely to keep the practice stable-at least for now.

Between competitors, the situation is less clear. A recent example of this dispute arose when a competitor of the national law firm of Binder and

${ }^{185}$ 1-800 Contacts, Inc. v. Lens.com, Inc., 755 F. Supp. 2d 1151, 1169-70 (D. Utah 2010) (quoting J.G. Wentworth, S.S.C. LP v. Settlement Funding LLC, No. 06-0597, 2007 U.S. Dist. LEXIS 288, at *13 (E.D. Pa. Jan. 4, 2007)).

${ }^{186}$ Network Automation, Inc. v. Advanced Sys. Concepts, 638 F.3d 1137, 1144 (9th Cir. 2011).

${ }^{187}$ Rescuecom, 562 F.3d at 130. See also MCCARTHY, supra note 175 , at $\$ \S 23: 11.50$, 25:70.15.

${ }^{188}$ See, e.g., Network Automation, 638 F.3d at 1145.

${ }^{189}$ Rescuecom, 562 F.3d at 130 n.4.

${ }^{190}$ Binder v. Disability Grp., Inc., 772 F. Supp. 2d 1172, 1174 (C.D. Cal. 2011). See also Steven Levy, How Google's Algorithm Rules the Web, WIRED (Feb. 22, 2010, 12:00 PM), http://www.wired.com/magazine/2010/02/ff_google_algorithm. 
Binder purchased the firm's trademark for advertising. ${ }^{191}$ The district court analyzed the dispute as follows:

The Defendants do not dispute that they used Plaintiffs' mark in their Google AdWord [sic] campaign. Moreover, we find as a matter of fact that Defendants used the "Binder and Binder" mark in a Google AdWord [sic] campaign. We find that Defendants bid successfully on the name with the result that Defendants' website appeared as a sponsored link on Google when potential customers searched for Plaintiffs' trademarked name. Thus, the only two elements in dispute are Plaintiffs' ownership of the marks and the likelihood of confusion. ${ }^{192}$

The district court addressed all the likelihood-of-confusion factors and determined that the use of an identical mark in keyword advertising, along with evidence of actual confusion, constituted sufficient evidence to support a finding of likelihood of confusion. ${ }^{193}$ The court also found false advertising and state law liability. ${ }^{194}$

As a jurisprudential matter, the Ninth Circuit has reasserted that the entire likelihood-of-confusion test-not merely a subset-should be used to address likelihood of confusion. ${ }^{195}$ The Ninth Circuit had previously narrowed the test for Internet-based initial interest confusion: "In the context of the Web in particular, the three most important Sleekcraft factors are (1) the similarity of the marks, (2) the relatedness of the goods or services, and (3) the simultaneous use of the Web as a marketing channel." ${ }^{\prime 196}$ The court has since retreated from this subset of factors. ${ }^{197}$ As demonstrated by the facts of Binder v. Disability Group, Inc., actual confusion may prove a compelling reason to find that the particular use of another's keyword advertising is actionable. ${ }^{198}$

As with Binder, other lawsuits suggest substantial confusion can result from using a competitor's trademark in keyword advertising and the paid

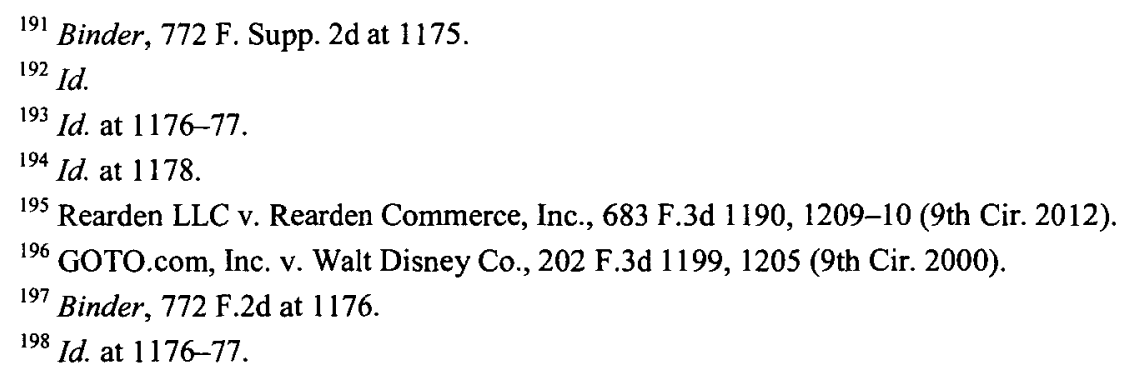


link ads they generate ("Sponsored Links"). ${ }^{199}$ "According to the survey results, $67.6 \%$ of test group respondents expected that they would reach GEICO's Web site if they clicked on the Sponsored Links, and $69.5 \%$ thought that the Sponsored Links were either links to GEICO's site or affiliated with GEICO in some way., 200 The numbers speak for themselves, supporting a finding of likelihood of confusion for Sponsored Links. ${ }^{201}$

As a practical matter, Congress may wish to step into this arena. While using another's trademark for nominative or descriptive fair use remains applicable to keyword advertising in the same fashion as it applies to domain names, metatags, and traditional media, the use causes a serious economic harm because of too little trademark protection. Were all keyword advertising permitted, then the effect is not to improve consumer access to competitive products so much as it is to allow the search engines companies to drive up the cost of keyword advertising through the bidding process used to purchase the keywords.

Put another way, Google and Bing increase their profitability when multiple bidders want the top listing for the same term. If a company's direct competitor can bid to rank higher in the sponsored listing, the company must either pay more to use its own name or give ground to its rival. Google and Bing make ever-increasing profits. ${ }^{202}$

${ }^{199}$ Gov’t Emps. Ins. Co. v. Google Inc., 77 U.S.P.Q.2d (BNA) 1841, 1846 (E.D. Va. 2005).

${ }^{200} \mathrm{Id}$.

${ }^{201}$ Id. at 1847.

${ }^{202}$ The companies do provide some relief to trademark holders, with some jurisdictions demanding far greater trademark scrutiny than the United States. As a result, the Google trademark policy is illustrative:

Google recognizes the importance of trademarks. Our AdWords Terms and Conditions prohibit intellectual property infringement by advertisers. Advertisers are responsible for the keywords they choose to trigger their ads and the text they choose to use in those ads.

Google takes allegations of trademark infringement very seriously and, as a courtesy, we investigate matters raised by trademark owners.

Advertising Policy: Help for Trademark Owners, GooGLE, http://support.google.com/ adwordspolicy/bin/answer.py?hl=en\&answer=2562124 (last visited Feb. 22, 2013). 
The consumers pay for the cost of advertising in the continuously increasing price of their goods. ${ }^{203}$ Moreover, to the extent that the search engines actively suggest the use of the trademarks as keywords, they induce competitors to use each other's marks to maximize rankings.

Careful study must be undertaken to determine whether the effect is to increase competition and access of products for consumers or merely to enrich the search engine companies at the expense of the public and the less-well financed corporate competitors. Any solution must maintain expansive fair use rights and uses that serve a competitive commercial purpose-such as parody, comment or criticisms. Nonetheless, the public's interest must be assessed.

\section{Final Words-Eternal Diligence}

Trademark management invariably starts with an ongoing policing of the mark. This can be accomplished with the tools made available by search engines, ${ }^{204}$ the ongoing monitoring of the use of a trademark online, and the regular assessment of the trademarks used by others. Nonetheless, diligence and engagement remains the most critical step.

Many of the battles over trademark rights stem from parties having spent a good deal of time, effort, and money on establishing the use of the trademark. $^{205}$ The earlier a trademark owner can alert a third party to the problems associated with the use, the more likely that party will accommodate the request. ${ }^{206}$

At the same time, eternal diligence should not equate to zero tolerance. Trademark owners make constant use of fair use, and as such, companies should be mindful of the key functions their trademarks serve for others.

\section{CONCLUSION}

In the relatively short time since laws were enacted to protect service providers from defamation lawsuits and Internet companies from secondary liability for copyright infringement, the role of the Internet has

${ }^{203}$ Thomas L. Eovaldi, The Market for Consumer Product Evaluations: An Analysis and a Proposal, 79 Nw. U. L. REv. 1235, 1240 n.24 (1985).

${ }^{204}$ Advertising Policy: Help for Trademark Owners, supra note 202.

${ }^{205}$ Melissa Ung, Trademark Law and the Repercussions of Virtual Property (IRL), 17 COMMLAW CONSPECTUS 679, 696 (2008).

${ }^{206}$ See Leah Chan Grinvald, Shaming Trademark Bullies, 2011 WIS. L. REV. 625, 63839. 
transformed into a central part of all communications strategies and has integrated into the global village's daily life.

In less than two decades, the mores of the Internet have transformed from the Wild West to the Town Square, and the interpretation of the intellectual property and media laws that shape the Internet have kept pace. As this Article suggests, inconceivable problems of domain names and illegal cyber posts are now handled routinely. There remain instances of both overprotection and underprotection, content owners that thump chests and threaten all, as well as self-anointed activists who respect no ownership, but the extremism at the margin does not define Facebook's 845 million monthly users or affect more than a mere fraction of the 250 million photographs uploaded daily. ${ }^{207}$ If the numbers say anything, they suggest the system largely works.

Still, for each innovation, there is new wine to be served-sometimes in new bottles, sometimes in old. Innovation continues at a breathtaking pace, so the only thing certain is that today's solutions will soon transform into tomorrow's challenges. For content owners, this suggests three essential steps for success: (i) diligence in all policing efforts; (ii) moderation and measured responses in terms of time, effort, and expense to each unauthorized use; and (iii) a sense of humor-because this too shall pass.

The Internet will never be pristine, but perhaps this will help tidy it up a bit.

${ }^{207}$ Facebook, Inc., Registration Statement (Form S-1) (Feb. 1, 2012), available at http:/www.sec.gov/Archives/edgar/data/1326801/000119312512034517/d287954ds1.htm\# toc287954_2. 